\title{
SECURITY INTERESTS IN BOOK-ENTRY SECURITIES IN JAPAN: SHOULD JAPANESE LAW EMBRACE PERFECTION BY CONTROL AGREEMENT AND SECURITY INTERESTS IN SECURITIES ACCOUNTS?
}

\author{
KUMIKO KOENS \\ AND \\ ChARles W. MOONEY, JR. *
}

\begin{abstract}
* Koens is Professor, Faculty of Literature and Social Sciences, Yamagata University, and Mooney is Charles A. Heimbold, Jr. Professor of Law, University of Pennsylvania Law School. We are grateful for valuable comments and suggestions made by Hideki Kanda (Professor, Gakushuin University Law School, Professor Emeritus, University of Tokyo Faculty of Law and Graduate School of Law and Politics) and the other participants at a seminar hosted by the Bank of Japan's Institute for Monetary and Economic Studies in Tokyo on July 21, 2015, and by Hatsuru Morita (Professor, Tohoku University) and Akira Tokutsu (Associate Professor, Tohoku University) and the other participants at a seminar hosted by the Tohoku University Law School in Sendai on January 7, 2016. We also wish to thank Marek Dubovec (Senior Research Attorney, National Law Center for InterAmerican Free Trade), Katsuhiko Fujihira (Partner, Morrison \& Foerster), Steven L. Harris (Professor, Chicago-Kent College of Law), Tatsu Katayama (Partner, Anderson, Mōri \& Tomotsune), Hiroo Sono (Professor, Hokkaido University), Masahiro Ueno (Partner, Nishimura \& Asahi), and Keiko Yamamoto (Bank of Japan, Institute for Monetary and Economic Studies) for valuable comments on earlier drafts. We also thank Masayuki Oka (Bank of Japan, LL.M. 2015, University of Pennsylvania Law School), whose paper (prepared under Mooney's supervision) has been helpful to the authors. See Masayuki Oka, Difference of Security Interest Perfection in Securities between the U.S. and Japan-Relationship between Securities Intermediaries and Account Holders (May 2015) (on file with authors).
\end{abstract}




\section{TABLE OF CONTENTS}

1. Introduction......................................................................763

2. Drafting and Intellectual History of the CA-SA Approach: Relevant Statutory Provisions of the Uniform Commercial Code and Geneva Securities Convention .........771

2.1. Perfection by Control Agreement. ..........................................772

2.1.1. UCC Articles 8 and 9..............................................772

2.1.2. Geneva Securities Convention. ...................................780

2.2. Security Interests in Securities Accounts. ...........................785

2.2.1. UCC Articles 8 and 9.............................................785

2.2.2. Geneva Securities Convention. ..................................789

3. Overview of Proposals for CA-SA Approach and Transactional Roles of Agreements Supplementing Control Agreements

4. Security Interests Under the Japanese Book-Entry Transfer Act.

5. Proposed Revisions of Japanese Book Entry

Transfer Act: Policy Analysis.

5.1. Conceptual Consistency of Proposal with Book Entry

Transfer Act and Traditional Japanese Property Law..

5.2. Perfection by Control Agreement and Security Interests in Securities Accounts.

5.3. Implications for Priority Rules and Priority Contests ..........816

5.4. Right of Retention under Japanese Civil Code (Minpō) and Commercial Code (Shōhō)...

6. Transactional Context in Japan: Are the Proposed Revisions a Good Fit, a Wasteful Diversion, or a Prudent Risk?.

7. Summary and Conclusions. 


\section{INTRODUCTION}

Collateral - primarily financial assets such as securities - is central to the operation of the financial markets. Such collateral secures a great variety of obligations. In the introduction to her pathbreaking 2011 book, written in the wake of the recent financial crisis, Annelise Riles put it this way:

"Everywhere one turns today industry experts, government officials, and members of the media are decrying the weak legal, analytical, and ethical foundations of the global swap markets. But if swaps are seen as economically irrational, financially dangerous, and prone to ethical abuse, another dimension of the same market has emerged as solid, respected, and even morally and ethically empowered, what George Soros recently referred to as 'motherhood and apple pie' $^{\prime} .$. That element is collateral. Collateral seems to have survived the tectonic shifts in market ideologies of the last few years with its reputation intact when so much else of what once was unquestionable dogma - free markets, selfregulation, the innate brilliance and rationality of derivatives traders-now seems like a quaint mythology from a strange other world." 1

She continued as follows:

"[C]ollateral, as a private technology of regulation, has emerged as a quiet nexus of tremendous political and economic legitimacy - within the market, the government, and the wider political sphere-at a moment at which both markets and their regulation are facing a dramatic legitimacy deficit internally and externally." 2

This paper deals with a particular type of collateral in a particular setting-securities credited to securities accounts governed by Japanese law. It considers and proposes some significant, but

1 AnNelise Riles, Collateral KnOWledge 1 (2011).

$2 I d$. at 4. 
quite plausible, modifications of Japan's Act on Transfer of Bonds, Shares, etc. (Book-Entry Transfer Act, or BETA). ${ }^{3}$ The proposed revisions are inspired by and patterned on similar provisions in Articles 8 and 9 of the Uniform Commercial Code (UCC), which have been enacted in substantially uniform fashion in every state of the United States. In this respect the proposed revisions are in good company. The Legislative Guide on Secured Transactions ${ }^{4}$ and the Draft Model Law on Secured Transactions, ${ }^{5}$ each a work product of the United Nations Commission on International Trade Law (UNCITRAL), and the Cape Town Convention ${ }^{6}$ and the Geneva Securities Convention (GSC), ${ }^{7}$ each a product of International Institute for the Unification of Private Law (UNIDROIT), also were substantially influenced by analogous provisions in the UCC.

The BETA became fully operative for all publicly traded securities in 2009.8 Enactment of the BETA was an important step in the

3The Act on Transfer of Bonds, Shares, etc., Act No. 75 of 2001, as amended in 2002 (Act 65 of 2002), 2004 (Act 88 of 2004), and 2014 (Act No. 91 of 2014) [hereinafter BETA].

4 U.N. Nations COMM'N ON INT'L TRAde LAW [UNCITRAL], Legislative Guide ON SECURED TRANSACTIONS, U.N. Sales No. E.09.V.12 (2010), at http://www.uncitral.org/pdf/english/texts/security-lg/e/09-82670_EbookGuide_09-04-10English.pdf [https://perma.cc/LU47-8RMT] [hereinafter UNCITRAL Legislative Guide on Secured Transactions]; see also UNCITRAL, GUIDE ON THE IMPLEMENTATION OF A SECURITY RigHTS REGISTRY, U.N. Sales No. E.14.V.6 (2014), at http:/ / www.uncitral.org/pdf/english/texts/security/Security -Rights-Registry-Guide-e.pdf [https://perma.cc/Y89N-S2QH].

5 See Int'1 Law Comm'n, Draft Model Law on Secured Transactions, Rep. on the Work of Its Twenty-Eighth Session, U.N. Doc. A/CN.9/865, at https:// documents-dds-ny.un.org/doc/UNDOC/LTD/V15/052/64/PDF/V1505264. pdf?OpenElement [https:// perma.cc/4MLU-7D34] [hereinafter UNCITRAL Draft Model Law on Secured Transactions].

6 Int'1 Inst. for the Unification of Priv. L. [UNIDROIT], Convention on International Interests in Mobile Equipment, 2307 U.N.T.S. 285 (Nov. 16, 2001), at http:// www.unidroit.org/instruments/security-interests/cape-town-convention [https://perma.cc/5SGP-FN7Q]; see also UNIDROIT, Protocol to the Convention on:s-Matters Specific to Aircraft Equipment (Nov. 16, 2001), at http:// www.unidroit.org/instruments/security-interests/aircraft-protocol [https:// perma.cc/2FFA-K76H].

7 UNIDROIT, Convention On Substantive Rules For Intermediated Securities (Oct. 9, 2009), at http://www.unidroit.org/instruments/capital-markets/genevaconvention [https://perma.cc/9CNZ-EC9A] [hereinafter Geneva Securities Convention or GSC]; see also UNIDROIT, Final Act of the Final Session of the Diplomatic Conference to Adopt a Convention on Substantive Rules Regarding Intermediated Securities, CONF 11/2 - Doc 41, http://www.unidroit.org/english/conventions/ 2009intermediatedsecurities/conference/conferencedocuments2009/conf11-2041-e.pdf [https://perma.cc/94VM-Z652].

8 In that year the BETA became fully operational for equity securities. Cabi- 
modernization of the Japanese financial markets. The Act instituted a modern book-entry system for the holding and transfer (including pledges) of interests in dematerialized securities. ${ }^{9}$ It also provided core reforms of the "back office" systems of the Japan Securities Depository Center, Inc. (JASDEC), Japan's central securities depository (CSD) for securities other than Japanese Government Bonds (JGBs), and Japan Securities Clearing Corporation (JSCC), which functions as a central counter-party, or CCP. ${ }^{10}$

In a book chapter published in 2010, Professor Hideki Kanda and one of us (Mooney) suggested consideration of some possible adjustments to the BETA and related Japanese law. ${ }^{11}$ That chapter focused primarily on the operation of the Geneva Securities Convention, as viewed from the perspectives of United States and Japanese law. ${ }^{12}$ (In this paper we generally use the terminology used and defined in the GSC: "Securities"13 are credited to a "securities account"14 (thereby constituting "intermediated securities"15) main-

net Ordinance No. 350 of 2008. When originally enacted in 2001, the BETA applied only to short term corporate debt (i.e., commercial paper). It was extended to all debt securities in 2002 and to equity securities in 2004. See supra text accompanying note 3 .

9 For an overview of the operation and functions of the BETA, see Charles W. Mooney, Jr. \& Hideki Kanda, Core Issues Under the UNIDROIT (Geneva) Convention on Intermediated Securities: Views From the United States and Japan, in INTERMEdiated SECURITIEs: Legal Problems AND PRACTICAL Issues 81-82, 86, 93 94, 103-04, 113-14 (Louise Gullifer \& Jennifer Payne eds., 2010) [hereinafter Mooney \& Kanda, Core Issues].

10 For a brief overview of the operations of JASDEC and JSCC in the clearance and settlement process, see $i d$. at 61-66, 114 and accompanying text.

11 Id. at $118-19$.

12 Id. (passim). Mooney served as a member of the United States delegation and Kanda served as a member of the Japanese delegation at the four meetings of the Committee of Governmental Experts and at the 2008 first session and the 2009 final session of the diplomatic conference. Kanda also served as the chair and Mooney also served as a member of the drafting committee at each of the experts' meetings and at both sessions of the diplomatic conference.

13 The GSC defines "securities" broadly to mean "any shares, bonds or other financial instruments or financial assets (other than cash) which are capable of being credited to a securities account and of being acquired and disposed of in accordance with the provisions of this Convention." GSC art. 1(a).

14 A "securities account" is "an account maintained by an intermediary to which securities may be credited or debited." GSC art. 1(c).

15 See GSC art. 1(b) (defining "intermediated securities" as "securities credited to a securities account or rights or interests in securities resulting from the credit of securities to a securities account"). Except for specific references to the term in the context of the GSC, we use this term throughout the paper to refer generally to securities held through an intermediary. 
tained with an "intermediary"16 in the name of an "account holder"17).

One suggestion was to adopt the control agreement method of making a transfer of an interest in intermediated securities effective against third parties (e.g. in UCC Article 9 terminology, a "perfected" "security interest"18) as an alternative to effecting a pledge or other transfer by book entries. ${ }^{19}$ (We refer here to this method as the CA approach.) This method of creating an effective interest is a practical approach that fits well with the Japanese book-entry system, although additional conceptual analysis and exploration of its compatibility with current Japanese secured transactions is need-

\footnotetext{
16 "Intermediary" is defined as "a person (including a central securities depositary) that in the course of a business or other regular activity maintains securities accounts for others or both for others and for its own account and is acting in that capacity." GSC art. 1(d). An English translation of the corresponding term used in the BETA for an intermediary other than a CSD is "account management institution" (kōza kanri kikan). BETA art. 2(4). This terminology is consistent with the principle that under the BETA the intermediary does not have a property interest in securities credited to accounts of its account holders as only the account holder at the lowest tier - the beneficial owner - is presumed to hold ownership of the securities. BETA arts. 76 (corporate debt securities); 101 (JGBs); 143 (corporate equity securities). Such an account holder is a "participant" (kanyūsha). BETA art. 2(3). A CSD is a "book-entry transfer institution" (furikae kikan). BETA art. 2(2).

17 "Account holder" is defined as "a person in whose name an intermediary maintains a securities account, whether that person is acting for its own account or for others (including in the capacity of intermediary)." GSC art. 1(e).

18 The concept of "perfection" of a "security interest" is borrowed from Uniform Commercial Code (UCC) Article 9. See U.C.C. §§ 9-308(a) (in general, a security interest is perfected when it has attached (i.e., has been created) under UCC $\S$ 9-203 and the applicable perfection step or steps have been satisfied). See U.C.C. § 1-201(b)(35) (defining "security interest"). The UCC is a "uniform law" promulgated under a joint venture between the National Conference of Commissioners on Uniform State Laws and The American Law Institute. Actually, it is not a "law" at all, but simply a model promulgated with the expectation that the various states of the United States will enact it. Like any uniform law, it must be adopted by a state before it becomes law. UCC Articles 8 (investment securities) and 9 (secured transactions) have been adopted by every state in substantially uniform form. "Perfection" has become a term widely used around the world to refer to the general effectiveness of a security interest as against third parties.

19 A control agreement provides that an intermediary agrees (with the consent of the account holder) that it will comply with instructions of a transferee without further consent of the account holder. See generally infra Part 2.1. A corollary of control agreement effectiveness is that if the transferee is the account holder's own intermediary then a control agreement is not necessary -it would make little sense for the intermediary to agree to comply with its own instructions to itself. Id. Once the account holder agrees to the terms of the transfer, the transfer to the intermediary is effective against third parties without any further steps. Id.
} 
ed.20 As explained further below, the legal framework for bookentry securities under the BETA relies heavily on the role of book entries, which are central to the system. Under the current system for pledges of securities as well as jōto tanpo transfers of security interests (outright assignment or title transfer), book entries are required. Consistent with the approach taken here, it has been suggested that the fundamental theories and structures of book-entry systems should be reconsidered with a focus on the role and function of intermediaries. ${ }^{21}$

A second suggestion by Mooney and Kanda was to provide for the transfer and creation of an effective interest in a securities account-i.e., in any securities that from time to time are credited to a securities account-again, without book entries with respect to specific securities subject to the transfer. This approach would incorporate the concept of a "floating lien" on securities so credited, without the need for book entries or even specific descriptions of the securities. (We refer here to this approach as the SA approach and to these two suggestions, together, as the CA-SA approach.) As suggested above, similar provisions in UCC Articles 8 and 9 and in the GSC inspired these two suggestions. A third suggestion was for Japanese law to recognize the holding of an interest in securities by a beneficial owner through a nominee to whose securities account the securities are credited.

Given the broad scope of their chapter, Mooney and Kanda did not pursue there a thorough examination and evaluation of these possible revisions of Japanese law. This paper takes that next step with respect to two of the suggested revisions - the control agreement method of effectiveness and the transfer of an interest in a securities account. These revisions would complement the BETA as currently in effect and would fit squarely within the Act's goal of providing an efficient and reliable framework for the transfer of in-

20 Hiroyuki Kansaku, Denshikasareta Yükashōken no Tanpoka - "Shihai" niyoru Tannpoka, in 22 KINYŪ Hō MU KENKYŪ KAI Hō KOKUSHO, Yū KASHō KEN NO Pépā RESUKAT̄̄ NI TOMONAU TANPOKENNADO KINYū TORIHIKI NikAKaru Hō TEKIMONDAI, 12, 21-30 (2013); Kumiko Koens, Furikaeseido niokeru Shōken oyobi Shōkenkōza no Tanpoka: "Shihai" niyoru Tanpoken no Settei nitsuite [Securities and Securities Accounts Under the Book-Entry System: Creating an Effective Security Interest by Means of a Control Agreement], 62 YAMAgATA U. J. L. \& POL. 57, 78-89 (2015) (JAPAN).

21 Kumiko Koens, Shōkenfurikaeseido ni okeru Kōzakanrikikan no Hōtekichii to tanpoken: Tōshishintaku niokeru Juekisha no Hasan no Jian wo Sozai toshite [The Legal Role of Securities Intermediaries in the Modern Securities Holding and Transferring System in Japan], 45 Bull. YAMAgATA U. (SOCIAL SCIENCE), no. 1, 2014, at 1, 8-12. 
terests in securities credited to securities accounts. In this connection, Part 5 contains the principal normative content of the paper; in many respects it is the heart of the paper. In that part we explain that the CA-SA approach is conceptually consistent with the BETA and with traditional Japanese property law. We also explore the policy arguments in support of adopting the CA-SA approach. In addition Part 5 explains that the CA-SA approach would require the adoption of priority rules and, to protect book-entry transferees, "cut-off" or "takes free" rules. It also considers the CA-SA approach in light of the right of retention rules provided in the Japanese Civil Code (Minpō) and the Japanese Commercial Code (Shō hō).

We should highlight here the terminology that we employ throughout this paper. We sometimes refer to a "pledge" of bookentry securities because the accepted translation of the BETA provides for book-entry pledges and the proposals we advance here would supplement those provisions. Our proposals could accommodate security interests (i.e., interests in book-entry securities that, pursuant the parties' agreement, secure obligations of a debtor to a creditor), including security interests in the form of outright title transfers under Japanese law, i.e., jōto tanpo transfers, as well as outright transfers of other interests such as outright transfers of title in repurchase agreement (repo) transactions and transfers of limited (e.g., fractional) interests. Our references to a "pledge," "pledgor," and "pledgee" in the context of book-entry securities contemplate only book-entry pledge transactions within the meaning of and the framework of the BETA. ${ }^{22}$ Our references to a "security interest" contemplate both such a book-entry pledge as well as other security interests, including jōto tanpo title transfer security interests. Our references to a "transfer," "transferor," and "transferee" contemplate any type of transfer of an interest. ${ }^{23}$ The terminology used here is summarized in Figure I.1:

22 See infra Part 4 (discussing mechanics of book-entry pledges under the BETA).

23 See infra Parts 4, 5.3. (discussing the application of our proposals to outright transfers). 


\section{FIGURE I.1 \\ SUMMARY OF TERMINOLOGY}

$\begin{array}{lll}\text { Pledge } & = & \begin{array}{l}\text { Book-entry pledges under the } \\ \text { BETA }\end{array} \\ \text { Security interest }= & \begin{array}{l}\text { Pledges and other security inter- } \\ \text { ests, including title transfer as secu- } \\ \text { rity }(j \bar{o} \text { to tanpo })\end{array} \\ \text { Transfer } & =\quad \begin{array}{l}\text { Security interests and other trans- } \\ \text { fers of interests, including transfers } \\ \text { of limited interests }\end{array}\end{array}$

A further note on the approach and scope of the paper is warranted. In general we favor the adoption of modern, generally applicable secured transactions laws such as UCC Article 9, the regime advanced in the UNCITRAL Legislative Guide on Secured Transactions, ${ }^{24}$ and the Draft Model Law on Secured Transactions currently being prepared by a working group of UNCITRAL. ${ }^{25}$ Accordingly, we could support the inclusion of the CA-SA approach for security interests in book-entry securities under Japanese law in a generally applicable secured transactions law that would incorporate such important concepts as after-acquired property ("floating lien") and the securing of future obligations. ${ }^{26}$ That said, transfers of security interests and other interests in bookentry securities are important commercial transactions in their own right. For that reason, and in order to keep the paper within a manageable scope and to focus in particular on the CA-SA approach, we address the issues in the context of proposed revisions to the BETA. Another plausible approach would be the adoption of a freestanding law on non-book-entry transfers of interests in

24 See supra note 4.

25 See supra note 5.

26 In this connection, we appreciate that some members of the Japanese legal community may have reservations about piecemeal treatment of secured transactions law in separate laws that address certain types of property. On the other hand, the BETA itself is an example of such special legislation. Modifying the current statute to provide beneficial flexibility and efficiency would not be a deviation from the approach already taken for book-entry securities. 
book-entry securities. An example of a freestanding Japanese secured transactions law is the Act on Special Provisions, Etc. of the Civil Code Concerning the Perfection Requirements for the Assignment of Movables and Claims (PRAMC). ${ }^{27}$ But we do not suggest that such targeted revisions necessarily reflect an optimal legislative approach or that a broader approach toward secured transactions law would be inappropriate. ${ }^{28}$

Revising Japanese law to provide for recognition of nominee holding of securities implicates much more than adjustments to the BETA. An evaluation of nominee holding requires consideration of basic elements of Japanese property law. These elements include the rights of creditors and purchasers and the treatment of the interests of a nominee and a beneficial owner in the case of a nominee's insolvency proceeding. For this reason, consideration of the suggestion for recognition of nominee holding must await a future project.

We would be remiss if we failed to add a final introductory comment on emerging technologies in the world of financial market infrastructure-in particular, the block-chain (or distributed ledger) technology that underlies virtual currencies such as Bitcoin. ${ }^{29}$ An exploration of this topic is far beyond the scope of this paper. Perhaps, in time, block-chain technology or its progeny may transmogrify the intermediated holding systems as presently known. Even so, in our view, the functional perspective on the transfer and acquisition of interests in securities applied here would remain highly relevant and instructive.

Following this Introduction, Part 2 of the paper describes the structure and operation of a control agreement transaction and the

27 Dōsan oyobi Saiken no Jō to no Taikō Yōken ni kansuru Minpō no tokurei tō ni kansuru Hōritsu [Act on Special Provisions, etc. of the Civil Code Concerning the Perfection Requirements for the Assignment of Movables and Claims], Law No. 104 of 1998 as amended and renamed by Law No. 148 of 2004 [hereinafter PRAMC].

28 Note that even if the CA-SA approach were incorporated into a generally applicable secured transactions law some special rules applicable only to bookentry securities no doubt would be necessary. Certainly this is the case with UCC Articles 8 and 9.

29 See, e.g., Depository Trust AND Clearing Corporation, EMbracing DisRUPtION, TAPPING THE POTENTIAL OF Distributed LEDGERS TO IMPROVE THE POSTTRADE LANDSCAPE (2016), http://www.dtcc.com/news/2016/january/25/ blockchain-white-paper; OLIVER WYMAN \& EUROCLEAR, BLOCKCHAIN IN CAPITAL MARKETS, THE PRIZE AND THE JOURNEY (2016), http://www.oliverwyman.com/ content/dam/oliver-wyman/global/en/2016/feb/BlockChain-In-Capital-

Markets.pdf [http:// perma.cc/N8DP-NF2P]. 
acquisition of an interest in a securities account. It explains the historical origins of these concepts in connection with the revisions of Articles 8 and 9 of the UCC and as subsequently adopted by the GSC. Part 3 then provides an overview of the proposal for the CASA approach under the BETA and explains the transactional roles of agreements that may supplement a control agreement. Part 4 next describes the pledge of securities under the BETA and explains how the Act could be revised to adopt the proposed control agreement effectiveness and the transfers of interests in securities accounts. Part 4 also identifies some troublesome aspects of the BETA's treatment of jōto tanpo security interests made effective by book entries in the context of a jōto tanpo transferee's insolvency and the rights of creditors of a jōto tanpo transferee. Part 5 next presents the core of the paper. It provides a policy analysis of the proposed control agreement effectiveness and transfers of interests in securities accounts. As indicated above, we conclude that these revisions would fit well with the underlying policies and the basic structure of the BETA, and further that on balance the revisions would be beneficial. Building on the analysis in Part 5, Part 6 takes account of the circumstance that control agreement effectiveness and transfers of interests in securities accounts currently are unknown in the Japanese financial markets. We argue that, based on the United States experience, adopting the CA-SA approach for the BETA could provide a useful and important tool that would offer enhanced transactional flexibility. We also argue that it is plausible that over time the Japanese markets would embrace and utilize the proposed revisions and, accordingly, that new transactional patterns would emerge. Part 7 then summarizes and concludes the paper.

\section{DRAFTING AND INTELLECTUAL HISTORY OF THE CA-SA APPROACH: RELEVANT STATUTORY PROVISIONS OF THE UNIFORM COMMERCIAL CODE AND GENEVA SECURITIES CONVENTION}

This Part describes the structure and operation of a control agreement transaction and the acquisition and effect of the transfer of an interest in a securities account. It also provides background on the historical origins of these concepts in connection with the revisions of UCC Articles 8 and 9 and as subsequently adopted by the GSC. The discussion of each topic (control agreement and then 
securities account) considers the relevant text of UCC Article 8 (and 9, where applicable) and the GSC. As background, the discussion considers some of the pertinent drafting history that eventually led to the adoption of the relevant final texts of the UCC and the GSC.

\subsection{Perfection by Control Agreement.}

\subsubsection{UCC Articles 8 and 9}

Consider first an introduction to the relevant UCC terminology and statutory framework as currently enacted. When a "security" 30 or another "financial asset" 31 is credited by a "securities intermediary" 32 to a "securities account," 33 an "entitlement holder" 34 acquires a "security entitlement." 35 A security entitlement is a type of "investment property" 36 under UCC Article 9. A "security interest" 37 in investment property, including a security entitlement, may be perfected 38 by "control." 39 Perfection of a security interest generally provides priority over a subsequent judicial lien creditor 40 and the trustee in bankruptcy ${ }^{41}$ of a "debtor." 42 Article 9 also contains some special priority rules for investment property.43 A

\footnotetext{
U.C.C. § 8-102(a)(15) (defining "security").

U.C.C. § 8-102(a)(9) (defining "financial asset").

U.C.C. § 8-102(a)(14) (defining "securities intermediary").

U.C.C. § 8-501(a) (defining "securities account").

U.C.C. § 8-102(a)(7) (defining "entitlement holder").

U.C.C. § 8-102(a)(17) (defining "security entitlement").

U.C.C. § 9-102(a)(49) (defining "investment property").

U.C.C. § 1-201(b)(35) (defining "security interest").

38 See supra text accompanying note 18 .
}

39 U.C.C. § 9-314(a) (perfection by control). Control of a security entitlement is governed by section 8-106. U.C.C. §§ 9-106(a); 8-106. Perfection of a security interest in investment property, including security entitlements, also may be achieved by filiing a financing statement in the proper public office. U.C.C. §§ 9310(a); 9-312(a).

40 U.C.C. § 9-317(a)(2); 9-102(defining "lien creditor").

41 11 U.S.C. § 544(a)(1).

42 U.C.C. § 9-102(a)(28) (defining “debtor").

43 U.C.C. § 9-328. Conflicting security interests in security entitlements that are perfected by control generally rank in priority according to the time of obtain- 
"purchaser," 44 including a "secured party" 45 holding a security interest, obtains "control" of a security entitlement if "the securities intermediary has agreed that it will comply with entitlement orders ${ }^{[46]}$ originated by the purchaser without further consent by the entitlement holder." 47 However, the securities intermediary may so agree only with the consent of the entitlement holder. ${ }^{48}$ Such an agreement by a securities intermediary is generally referred to as a "control agreement," although that term itself is not defined in the UCC. If an entitlement holder grants an interest in its security entitlement to its own securities intermediary, the intermediary has control; no additional step or steps are necessary. ${ }^{49}$

When a purchaser has control of a security entitlement, the parties' agreement may afford the purchaser the exclusive right to originate entitlement orders to the exclusion of the entitlement holder. Similarly, if the entitlement holder's securities intermediary has control, the entitlement holder also may, by agreement, be precluded from originating entitlement orders. However, if the parties agree that the entitlement holder will retain the right to originate entitlement orders (subject to any agreed upon conditions or exceptions) or to make substitutions for the security entitlement, the purchaser or securities intermediary may nevertheless continue to have control.50

The current UCC statutory framework for security entitlements just described, including perfection of security interests in security entitlements by control, was largely developed during the process

ing control, except that a security interest held by the securities intermediay has priority over a security interest held by another secured party. U.C.C. § 9$328(2)(B)$, (3). If none of the special priority rules apply, then the general priority rules apply. U.C.C. §§ 9-328(7); see U.C.C. §§ 9-322; 9-323. Concerning applicable priority rules in connection with the CA-SA approach proposed here, see infra Part 4.3.

44 U.C.C. $§ 1-201(b)(29)$ (defining "purchase"), (30) (defining "purchaser").

45 U.C.C. § 9-102(a)(73) (defining "secured party").

46 U.C.C. § 8-102(a)(8) (defining "entitlement order").

47 U.C.C. \$ 8-106(d)(2). Control of a security entitlement also can be obtained "if . . the purchaser becomes the entitlement holder." U.C.C. § 8-106(d)(1). This is equivalent to a book-entry transfer of a security interest under the BETA by outright title transfer to a transferee's proprietary account (or jōto tanpo); there is no concept of a "pledge account" under the UCC. See infra Part 4.

48 U.C.C. § 8-106(g). A securities intermediary is not required to enter into a control agreement and is not required to confirm that it has entered into a control agreement unless the entitlement holder so requests. $I d$.

49 U.C.C. § 8-106(e).

50 U.C.C. $\S 8-106(f)$. 
for the revision of UCC Article 8 and conforming revisions to Article 9 which began in 1991 and which was completed in 1994 (1994 Article 8 Revisions). ${ }^{51}$ When UCC Article 9 was substantially revised in 1998 (effective in all states in 2001 or 2002), 52 the substantive framework established in the 1994 Article 8 Revisions was retained in almost all material respects. ${ }^{53}$

In the context of security entitlements, the "control" concept has roots in transactional patterns that had developed even before the Article 8 revision process had begun. So-called "tri-party repurchase (repo)" transactions provide an apt example. In such a transaction a securities transferor (dealer) and a securities transferee (investor/funds transferor) have accounts with the same intermediary - the dealer's clearing bank. On day-1 the repo securities are moved from the dealer's account to the investor's account and funds are moved from the investor's account to the dealer's account. On day-2 (assuming a typical overnight repo) the dealer repurchases the securities and the transfers of securities and funds (with a spread - return - for the investor) are reversed. ${ }^{54}$ Under a control agreement arrangement the same parties are involved. However, the control agreement governs the relationships among the dealer, investor, and dealer's clearing bank (intermediary) and there is no need for the investor actually to have a securities ac-

51 U.C.C. 1994 Official Text. For background on the process and preparatory work and an overview of the 1994 Article 8 Revisions, see Charles W. Mooney, Jr., Sandra M. Rocks, \& Robert S. Schwartz, An Introduction to the Revised U.C.C. Article 8 and Review of Other Recent Developments with Investment Securities, 49 Bus. Law. 1891 (1994). Mooney was the American Bar Association Section of Business Law's Advisor to the Drafting Committee for the Revision of U.C.C. Article 8. He attended all but one of the Drafting Committee meetings during the process and participated in the three 1992 Drafting Committee meetings and the 1992 Annual Meeting mentioned below.

52 U.C.C. 2001 Official Text, § 9-701 (uniform effective date of July 1, 2001). All but two states enacted the uniform effective date. Additional revisions to UCC Article 9 were promulgated in in 2010 (2010 Revisions) with a uniform effective date of July 1, 2013. U.C.C. 2010 Official Text, § 9-801. All states now have adopted the 2010 Revisions. Mooney was the Co-Reporter for the Drafting Committee to Revise Article 9 and was a member of the Joint Review Committee that prepared the 2010 Revisions.

53 See, e.g., U.C.C. §§ 9-106 (control of investment property) cmt. 1 (citing as source "Former Section 9-115(e)," which was added by the 1994 Article 8 Revisions); 9-328 (priority of security interests in investment property) cmt. 1 (citing as source "Former Section 9-115(5)", which was added by the 1994 Article 8 Revisions). (1988).

54 On tri-party repos, see generally Marcia STIGUM, AfTER THE TrAde 216-17 
count with the clearing bank.

Early on in the process leading to the 1994 Article 8 Revisions a consensus emerged that perfection of a security interest in securities, including those held in an account with a financial intermediary (the UCC's predecessor term for securities intermediary), should be achieved if the secured party has been given the power to dispose of the securities. The first public draft of UCC Article 8 (February 1992 Draft) produced in the process was discussed at a meeting of the Drafting Committee, advisors, and observers held in Philadelphia, February 21-23, 1992.55 The February 1992 Draft provided that "[i]n all cases, a security interest in a security may be perfected by the secured party having effective power of disposition over the security." 56 Section 8-107 of that draft further provided, in part:

(a)A person has "effective power of disposition" over securities owned by another if:

$\cdots$

(4) the securities are held in an account with a financial intermediary in the name of the secured party (or his designee other than a financial intermediary); or

(5)the securities are held for the owner in an account with a financial intermediary, and by written agreement among the owner, the financial intermediary, and the person, the person has the right, without specific notice to or consent from the owner, to instruct the financial intermediary to transfer the securities to the person or to any other person designated by the person. 57

Thus, albeit by another name and in language less compact and somewhat less artful than current law, the substance of perfection by control had emerged. The second public draft of UCC Article 8 was issued in 1992 (March 1992 Draft). It further refined the con-

55 Draft, Uniform Commercial Code Revised Article 8, Investment Securities, with Prefatory Note and Comments (February 5, 1992) [hereinafter February 1992 Draft] (on file with authors).

$56 \quad I d ., \S 8-604(\mathrm{a})$.

$57 \quad I d ., \S 8-107(\mathrm{a})(4),(5)$. 
cept of perfection by control and included conforming amendments to Articles 1 and 9.58 That draft was discussed at the Drafting Committee meeting held on March 27-29, 1992, in Chicago. The March 1992 Draft offered the first definitions of the terms "securities account entitlement" 59 and "control."

Section 8-501(a) of the March 1992 Draft provided: "The term 'securities account entitlement' means the rights of an account holder against a financial intermediary with respect to a security specified in subsections (b), ${ }^{[60]}(\mathrm{c}),{ }^{[61]}$ and $(d)^{[62]}$ of this section." Section 9-304 of that draft provided that "a security interest in investment property[63] may be perfected by the secured party having control over the security[64]." Under that draft a secured party would have "control" over a securities account entitlement if the secured party or its designee were the account holder ${ }^{65}$ or if:

by written agreement among the debtor, the financial intermediary, and the secured party, the financial intermediary has agreed to act on the account orders of the secured party, without specific notice to or consent from the debtor, to transfer the security to the secured party or to any other person designated by the secured party. ${ }^{66}$

58 Draft, Uniform Commercial Code Revised Article 8, Investment Securities (with Conforming Amendments to Articles 1 and 9), with Prefatory Note and Comments (March 12, 1992) [hereinafter March 1992 Draft] (on file with authors).

59 Note that this term is the forebear of the term "security entitlement" under current law. See supra note 35.

60 U.C.C. $\S 8-501$ (b) (account holder, as against financial intermediary, has right to have intermediary take action so that account holder has benefit of rights against issuer, such as voting rights).

61 March 1992 Draft, § 8-501(c) (account holder, as against financial intermediary, has right to have intermediary comply with authorized account orders pursuant to UCC section 8-503).

62 Id., § 8-501(d) (account holder, as against financial intermediary, has right to require intermediary to take steps to convert securities account entitlement to other form of securities holding).

63 Id.,\$ 9-105(1)(j) (defining "investment property" as "a security (defined in Section 8-102) or a securities account entitlement (defined in Section 8-501) to a security").

64 The term "investment property," instead of the term "security," probably should have been used here.

65 March 1992 Draft, supra note 58, § 9-304(7)(d).

$66 I d$. at $\S 9-304(7)(\mathrm{e})$. Note that subparagraphs (7)(d) and (7)(e) mistakenly refer to "a securities entitlement" instead of a "securities account entitlement." 
The next public draft was prepared for the 1992 Annual Meeting of the National Conference of Commissioners on Uniform State Laws, July 30-August 6, 1992 (1992 Annual Meeting Draft'67). The 1992 Annual Meeting Draft further refined the approach for dealing with control of securities account entitlements but without incorporating any major policy changes. Section 8-104 of that draft provided:

(a) In this Article "securities account entitlement" means the claim of a person against a broker or custodian in respect of a security or securities account entitlement that the broker or custodian

(1) has undertaken to hold on behalf of the person; and

(2) itself holds, or is to hold, in any form other than those specified in subsection (b)(i) or (b)(ii).

(b) A customer of a broker or custodian who has a claim against the broker or custodian in respect of a security is to be treated as owner of the security, rather than as the holder of a securities account entitlement against the broker or 2 custodian, only if:

(1) the security is registered in the name of, payable to the order of, or specially indorsed to the customer, and has not been indorsed to the broker or custodian or in blank; or

(2) the security is registered in the name of the broker or custodian as fiduciary for the owner, who is specifically identified on the records of the issuer.

The 1992 Annual Meeting Draft continued the approach of the previous draft for perfection of a security interest in a security account entitlement by control, but it added some additional detail. Section 9-304(7) of that draft provided:

(7) A security interest in investment property is perfected:

(a) if the secured party has control over the investment property;

67 U.C.C. $\S 8$ (AM. LAW INST. \& UNIF. LAW COMM'N, Annual Meeting Draft, 1992) [hereinafter 1992 Annual Meeting Draft] (on file with authors). 
(b) if the collateral is a securities account entitlement and the security interest is granted by the account holder to the financial intermediary through which the securities account entitlement is held;

(c) if the debtor is a broker; or

(d) if the debtor is not broker and a financing statement is filed.

Paragraph (7)(b) added the important feature of so-called "automatic" perfection when an account holder grants a security interest in a securities account entitlement to its own intermediary. ${ }^{68}$

Following the 1992 Annual Meeting, the final public draft of 1992 was produced (October 1992 Draft). ${ }^{69}$ The October 1992 Draft generally carried forward the policy and substance of the 1992 Annual Meeting Draft. Section 8-104 of the October 1992 Draft provided:

(a) In this Article "securities account entitlement" means the rights of a person against a financial intermediary and interest of the person in the property held by the financial intermediary in respect of a financial asset ${ }^{70}$ as to which the financial intermediary has undertaken to treat the person as beneficially entitled to the rights that comprise the financial asset.

(b) If a financial intermediary holds a financial asset on behalf of another, the other is to be treated as holding the financial asset directly, rather than as the holder of a securities account entitlement against the financial intermediary, only if the financial asset is registered in the name of, paya-

68 That feature now is incorporated into the concept of "control" of a security entitlement. U.C.C. § 8-106(e) (AM. LAW INST. \& UNIF. LAW COMM'N 2011-12) (“If an interest in a security entitlement is granted by the entitlement holder to the entitlement holder's own securities intermediary, the securities intermediary has control.").

69 U.C.C. § 8 (with Conforming Amendments to Article 9) (AM. LAW INST. \& UnIF. LAW COMM'N, Draft, Oct. 6, 1992) [hereinafter October 1992 Draft] (on file with authors).

$70 \quad I d$. § 8-105(a)(7) (defining "financial asset" to include "a security" as well as other assests susceptible of being credited to a securities account). 
ble to the order of, or specially indorsed to the other, and has not been indorsed to the financial intermediary or in blank. ${ }^{71}$

Section 9-603 of that draft provided, in part:

If the owner of a security or a securities account entitlement has granted an interest in the security or securities account entitlement to a secured party or to a repo claimant, the following rules determine whether the secured party or repo claimant has "control" over the security or a securities account entitlement:

(c) A secured party or repo claimant has control over a securities account entitlement if:

(1) the secured party or repo claimant is designated as the account holder of the securities account entitlement on the records of the financial intermediary through which the securities account entitlement is held; or

(2) the debtor or transferor of the securities account entitlement remains designated as the account holder, but by written agreement among the debtor or transferor, the financial intermediary through which the securities account entitlement is held, and the secured party or repo claimant, the financial intermediary has agreed that it will comply with account orders originated by the secured party or repo claimant, without further notice to or consent from the debtor or transferor. ${ }^{72}$

\footnotetext{
$71 \quad$ Id. $\S 8-104$.

72 Id. § 9-603(c). The Reporter's Notes to section 9-603 explained:
}

Although the defined term "control" is new, the concept is not. In essence, what the sections using this concept do is to place on a sound legal foundation the actual current practices of the securities industry. In repo transactions, for example, it is already quite common that a person who is advancing value on the security of investment securities enters into contractual arrangements with a third party custodian who agrees to hold the securities for the benefit of both the owner and the person advancing value, with the person advancing the value having the right to instruct the custodian as to the disposition of the securities in the event that the value is not repaid. Today, the legal effect of such arrangements rests on manipulation of the concept of "possession." 
Finally, Section 9-304 of the October 1992 Draft provided, in part:

(7)A security interest in investment property is perfected:

(a) if the secured party has control over the investment property;

(b) if the collateral is a securities account entitlement and the security interest is granted by the account holder to the financial intermediary through which the securities account entitlement is held;

$\ldots .^{73}$

During the process leading to the 1994 Article 8 Revisions, the Drafting Committee continued to refine the role and concept of control and the relevant definitions. However, the overall contours were well established early in the process as described in the foregoing discussion of the four 1992 public Drafts. While the control concept included a credit to a purchaser's securities accountequivalent to a book-entry security interest by outright assignment (jōto tanpo) under the Japanese BETA ${ }^{74}$ - it also embraced the CA approach of control through a control agreement without the necessity of a book entry.

\subsubsection{Geneva Securities Convention}

Article 12 of the GSC makes provision for the acquisition of an interest in intermediated securities other than by way of a credit to a securities account of an acquirer. ${ }^{75}$ Under Article 12(1) such an acquisition is achieved if the account holder so agrees ${ }^{76}$ and one of three conditions applies, if the relevant "Contracting State has

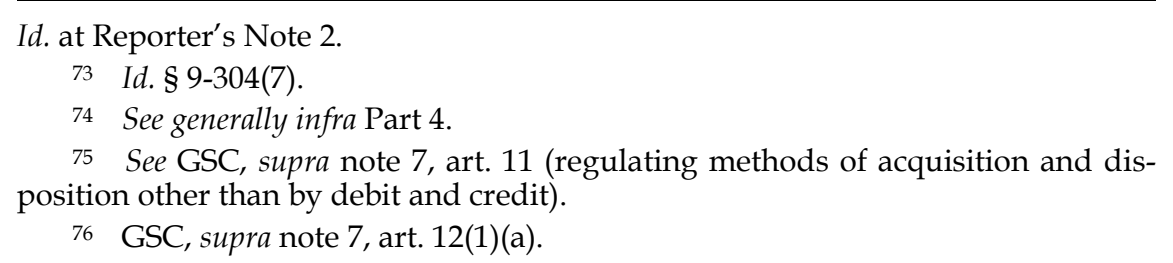


made a declaration" with respect to that condition. ${ }^{77}$ Article 12(3) provides:

3. The conditions referred to in paragraph $1(b)$ are as follows:

(a) the person to whom the interest is granted is the relevant intermediary; ${ }^{78}$

(b) a designating entry in favour of that person has been made;

(c) a control agreement in favour of that person applies. ${ }^{79}$

Subparagraphs (a) and (c) of Article 12(3) parallel the control concept under UCC Article 8.80 Neither the BETA nor the UCC adopt the designating entry method creating an effective interest. 81 As defined in the GSC, a "control agreement" is an agreement "between an account holder, the relevant intermediary and another person" (e.g., a creditor holding a security interest or another transferee). ${ }^{82}$ A control agreement may be negative or positive or both. A negative control agreement provides that the relevant intermediary may not comply with the account holder's instructions without the other person's (i.e., the transferee's) consent. 83 Negative control offers the benefit of preventing dissipation of the transferred securities. A positive control agreement provides that the relevant intermediary is required to comply with the other per-

77 GSC, supra note 7, art. 12(1)(b). A Contracting State may include one or more of the conditions in its declaration or it may choose not to make any declaration. GSC, supra note 7, art. 12(5)(a).

78 See GSC, supra note 7, art. 1(g) (defining "relevant intermediary" with respect to a securities account as "the intermediary that maintains that securities account for the account holder").

79 GSC, supra note 7, art. 12(3).

80 See generally supra Part 2.1.1.

81 A designating entry has the same effects as a control agreement under the GSC except that a designating entry involves an actual entry in the records of a security account but without debiting (withdrawing) the relevant securities from the account. See GSC, supra note 7, art. 1(1) (defining "designating entry").

82 GSC, supra note 7, art. 1(k). A control agreement also may, "if so provided by the non-Convention law, [be] between an account holder and the relevant intermediary or between an account holder and another person of which the relevant intermediary receives notice[.]" Id.

83 GSC, supra note 7, art. 1(k)(i). 
son's instructions "without any further consent of the account holder." 84 Positive control facilitates, for example, a transferee's enforcement of a security interest by disposition of securities upon the account holder's default. From a functional perspective, as with a physical pledge of certificated securities, a control agreement deprives the account holder of the power to dispose of the securities or provides such power to the transferee, or both.

UNIDROIT's Restricted Study Group on Harmonised Substantive Rules regarding Securities Held with an Intermediary began its work in 2002.85 In November 2004 the Restricted Study Group issued the first draft of its Preliminary Draft Convention on Harmonised Substantive Rules Regarding Securities held with an Intermediary. ${ }^{86}$ In addition to providing for the acquisition and disposition of securities held with an intermediary by credit and debit, 87 Article 4 of that draft provided specifically for the creation of a security interest (a term not defined in the draft) in such securities or over a securities account. ${ }^{88}$ Under Article 4 , such a security interest in favor of the relevant intermediary would be effective if the account holder and relevant intermediary so agree, without any further step. ${ }^{89}$ A security interest in favor of a person other than the relevant intermediary would be effective against third parties only if (i) the securities or securities account were designated "in a manner such that the relevant intermediary is committed to complying with any requirements which that other person may impose with respect to those securities or that securities ac-

84 GSC, supra note 7, art. 1(k)(ii).

85 UNIDROIT, STUDY LXXVIII DOC. 5, SUMMARY REPORT, RESTRICTED STUDY Group on ITEM 1 OF THE Project: Harmonised Substantive Rules For the Use of SECURITIES HELD WITH INTERMEDIARIES AS COLLATERAL (2002), http:/ /.unidroit.org/ english/documents/2002/study78/s-78-005-e.pdf [https://perma.cc/D6M289SY].

86 UNIDROIT, STUDY LXXVIII DOC. 18, PRELIMINARY DRAFT CONVENTION ON HARMONised Substantive Rules Regarding SECURITIES Held With AN INTERMEDIARY (2004), http://www.unidroit.org/english/documents/2004/ study78/s-78-018.pdf [https://perma.cc/J6ZC-VWT8] [hereinafter November 2004 Draft Convention]. The UNIDROIT Secretariat subsequently prepared Explanatory Notes to the Preliminary Draft Convention. UNIDROIT, STUDY LXXVIII Doc. 19, Preliminary Draft Convention on HaRmonised Substantive Rules REgARDing SECURITIES HELD WITH AN INTERMEDIARY (2004), http:// www.unidroit.org/english/documents/2004/study78/s-78-019-e.pdf [https:// perma.cc/C5S9-MMAE].

87 November 2004 Draft Convention, supra note 86, art. 3(1)-(3).

88 Id. art. 4. As to security interests in securities accounts, see infra Part 2.2.

89 Id. art. $4(1)(\mathrm{a})$. 
count[,]"90 and (ii) the relevant intermediary causes the securities account and relevant account statements "to be so annotated as to indicate the existence of the security interest." 91 This latter method applicable to other persons appears to be a precursor to the designating entry method of effectiveness ultimately adopted as an alternative in the GSC. 92

A second version of the preliminary draft convention emerged from the First Session of the Committee of Governmental Experts. ${ }^{93}$ The June 2005 Draft Convention replaced the somewhat cumbersome defined term "securities held with an intermediary" with the defined term "intermediated securities." 94 Article 6 of the June 2005 Draft Convention replaced Article 4 of the previous draft. Article 6(1) provided that a security interest in intermediated securities is effective against third parties upon an account holder's agreement with a "collateral taker" (a term not defined in the draft) as to the grant of the security interest ${ }^{95}$ and "delivering the intermediated securities into the possession or control of the collateral taker in accordance with paragraph 2[.]"96 Paragraph 2 then specified the methods of taking "possession or control" of intermediated securities: (i) credit of the intermediated securities to an account of the collateral taker, ${ }^{97}$ (ii) the relevant intermediary is the collateral taker,98 (iii) a designating entry is made in favor of the collateral taker, ${ }^{99}$ (iv) a control agreement is entered into in fa-

$90 \quad$ Id. art. $4(1)(\mathrm{b})$.

91 Id. art. 4(2).

92 See supra note 81 and accompanying text.

93 UNIDROIT, Study LXXVIII DOC. 24, PRELIMINARy DRAFT CONVENTION ON HARMONISED SubSTANTIVE Rules REgaRding INTERMEDIATED SECURITIES (2005), http://www.unidroit.org/english/documents/2005/study78/s-78-024-e.pdf [https://perma.cc/R26Q-55ZG] [hereinafter June 2005 Draft Convention]. The UNIDROIT Secretariat subsequently prepared a final report on the first session. UNIDROIT, STUDY LXXVIII DOC. 23, FINAL REPORT, FIRST SESSION, UNIDROIT COMMITTEE OF GOVERNMENTAL EXPERTS FOR THE PREPARATION OF A DRAFT

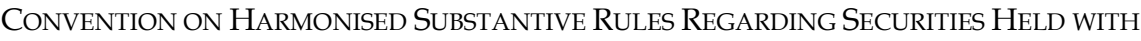
AN INTERMEDIARY (2005), http://www.unidroit.org/english/documents/2005/ study78/s-78-023rev-e.pdf [https://perma.cc/FS8N-AR4K].

94 See June 2005 Draft Convention, supra note 93, art. 1(f) (defining "intermediated securities" as "the rights of an account holder resulting from a credit of securities to a securities account").

95 Id. art. 6(1)(a).

96 Id. art. 6(1)(b).

97 Id. art. 6(2)(a).

$98 \quad I d$. art. 6(2)(b).

99 Id. art. 6(2)(c). This method and the control agreement method mentioned 
vor of the collateral taker, (v) the securities are held or designated in another manner specified in the relevant Contracting State's declaration as being sufficient under that state's law for the intermediated securities to be in the collateral takers possession or control.100 For present purposes, it is sufficient to note that the definitions of "control agreement" and "designating entry" in the June 2005 Draft were substantially the same as those ultimately included in the GSC. 101

As was the case in the development of the 1994 Article 8 Revisions, early on in the Committee of Governmental Experts stage of the GSC a consensus emerged that providing a third party with the power to instruct an account holder's intermediary was a touchstone for third party effectiveness of an interest in intermediated securities. ${ }^{102}$ And, as explained above, in each process the CA approach was embraced as a practical means of conferring such power. Also in each process, a consensus emerged that when the transferee of an interest was the account holder's own intermediary, no further effectiveness (perfection) step was necessary. Given the international nature of the process for developing the GSC, it is unsurprising that a more flexible approach was adopted, involving declarations by Contracting States as to the methods of effectiveness against third parties and inclusion of an additional method, designating entries. Given the more local nature of the UCC revision process, however, it also is unsurprising that the 1994 Article 8 Revisions adopted the filing of a financing statement as a perfection method for investment property under UCC Article 9.103 But the strong common thread through both processes is the recognition that interests of efficiency and practicality dictate the adoption of methods of transferring interests in intermediated securities without formal book entries.

next apply only if the relevant Contracting State has declared that a designating entry or control agreement is sufficient under that state's law for the intermediated securities to be in the collateral takers possession or control. Id.

100 Id. art. 6(2)(f).

101 Id. art. 1(m) (defining "control agreement"); id. art. 1(n) (defining "designating entry"); see supra notes 79-83 and accompanying text.

102 See UNIDROIT, STUDY LXXVIII DOC. 7, SUMMARY REPORT, RESTRICTED Study Group on ITEM 1 OF the Project: HaRMONised Substantive Rules REGARDING SECURITIES HELD WITH AN INTERMEDIARY 10 (2003), http:/ / www.unidroit.org/english/documents/2003/study78/s-78-007-e.pdf [https://perma.cc/CL3J-ZSNM] (mentioning perfection by control). 1994).

103 U.C.C. § 9-115(4)(b), Appendix XII (AM. LAW INST. \& UNIF. LAW COMM'N 


\subsection{Security Interests in Securities Accounts.}

Once one accepts the principle that the acquisition of an interest in intermediated securities may be made effective against third parties under the CA approach, without book entries, acceptance of the SA approach is a simple and logical next step. It is interesting, however, that in the drafting processes leading to the 1994 Article 8 Revisions of UCC Article 8 and to the GSC, it was the SA approach that surfaced earlier in the processes.

\subsubsection{UCC Articles 8 and 9}

Under UCC Article 9, a security interest in a securities account is a function of a description of collateral. Section 9-108(d) provides:

(d) [Investment property.] Except as otherwise provided in subsection (e), a description of a security entitlement, securities account, or commodity account is sufficient if it describes:

(1) the collateral by those terms or as investment property; or

(2) the underlying financial asset or commodity contract.

The Official Comment to Section 9-108 further explicates the meaning of the compact language of subsection $(\mathrm{d})$ :

[G]iven the broad definition of "securities account" in section 8-501, a security interest in a securities account also includes all other rights of the debtor against the securities intermediary arising out of the securities account. . . . Moreover, describing collateral as a securities account is a simple way of describing all of the security entitlements 
carried in the account. 104

Section 9-203(h) further provides: "The attachment of a security interest in a securities account is also attachment of a security interest in the security entitlements carried in the securities account."105 This approach is complemented by Section 9-204(a): "Except as otherwise provided in subsection (b) [relating to consumer goods and commercial tort claims], a security agreement may create or provide for a security interest in after-acquired collateral."106

This description-oriented approach to creating a security interest in a securities account is consistent with the thrust of the February 1992 Draft, which also treated the question of whether one could create a security interest in a securities account (i.e., in all securities from time to time credited to the account) merely as a function of the description of collateral. Section 8-603(1) of that draft provided:

Any description of collateral in a written security agreement is sufficient if it reasonably identifies the securities. A description identifying the collateral as all securities, or all securities of a given category, is sufficient. A description specifying a certain number of shares or units is sufficient whether or not specific securities are identified by certificate number or the like. ${ }^{107}$

In this context, "all securities now or hereafter credited to" a specified securities account, for example, would be "securities of a given category" within the meaning of the draft provision. ${ }^{108}$ Giv-

104 U.C.C. § 9-108, cmt. 4.

105 U.C.C. $\S 9-203(\mathrm{~h})$.

106 U.C.C. § 9-204(a); see also U.C.C. § 9-108, cmt. 5 (“[I]f the collateral consists of a securities account or commodity account, a description of the account is sufficient to cover all existing and future security entitlements or commodity contracts carried in the account.").

107 February 1992 Draft, supra note 55, § 8-603(1) (emphasis added).

108 Clearly this was the Reporter's intention:

The American Bar Association Section of Business Law Ad Hoc Committee on the Settlement of Market Transactions has recommended that some device be made available to permit the creation and perfection of security interests in all of the securities held by a person in an account at 
en that prior to the 1994 Article 8 Revisions a book entry was not required for the transfer of an interest in securities credited to a securities account, ${ }^{109}$ adopting this description-based approach was quite sensible. The March 1992 Draft closely followed the approach of the February 1992 Draft in this context. 110

Two provisions of the 1992 Annual Meeting Draft addressed more directly a security interest in a securities account. Section 9$110(\mathrm{~b})(2)$ of that draft provided, with respect to a description of collateral:

(b) In a security agreement or financing statement covering investment property:

$\ldots$

(2) a description identifying the collateral as all or a certain quantity of securities or securities account entitlement or all or a certain quantity of securities or securities account entitlement of a given category, or all or a certain quantity of securities or securities account entitlement held through a certain ac-

a financial intermediary. The specific device suggested by the ABA Committee was to permit the creation and perfection of a security interest in the securities account itself, as distinguished from a security interest in the securities held in that account. This section seeks to accomplish the same objective in a different fashion which, the Reporter believes, will be simpler and less likely to give rise to conceptual confusion that could result in uncertainty and unfortunate judicial decisions. Under this section the question whether a debtor is granting a security interest in one or more specific securities, or in a group of securities, or in all securities that it holds in a certain account with a certain financial intermediary, or in all securities that the debtor holds in whatever place or form, is treated simply as a matter of description of the collateral in the security agreement. This is the same approach taken in Article 9 for other forms of property.

Id., Reporter's Notes (emphasis added).

109 Under the 1978 U.C.C. Official Text, in the context of a securities account, a transfer of security interest would occur after a debtor signed a security agreement describing a security and "at the time a written notification ... signed by the debtor . . . is received by . . . a financial intermediary on whose books the interest of the transferor [debtor] in the security appears[.]" U.C.C., § 8-313(1)(h)(i) (AM. LAW INST. \& UNIF. LAW COMM'N 1978). Such a transfer was a necessary and sufficient method of attachment and perfection of a security interest as well. Id., § 8321(1), (2).

110 See March 1992 Draft, supra note 58, §§ 9-110 (sufficiency of description of investment property in security agreement); 9-203, Reporter's Note 3 (closely following Reporter's Notes to February 1992 Draft \& 8-603, quoted supra note 107). 
count is sufficient. 111

Section 9-319 of the 1992 Annual Meeting Draft addressed even more explicitly a security interest in a securities account. Section 9319 ("Security Interests in all Securities Account Entitlements in an Account") provided:

Except as otherwise provided in a security agreement, if a security agreement covers investment property and the description of the collateral indicates, by any form of words, that the debtor intended to grant a security interest in all securities account entitlements held in an account with a financial intermediary, or in the account itself, then:

(a) the security interest also attaches to all rights of the account holder against the financial intermediary arising out of the account, including credit balances whether or not they are proceeds of investment property, whether or not the rights would, taken individually, fall within the definition of investment property;

(b) any method of perfection that suffices to perfect a security interest in security account entitlements held in the account suffices to perfect the other rights described in subsection (a); and

(c) the security interest in the other rights described in subsection (a) has the same priority as the security interest in the securities account entitlements.

The October 1992 Draft's treatment of a security interest in securities account was consistent with the earlier drafts. Section 9110 of that Draft was consistent with the corresponding provision in the 1992 Annual Meeting Draft and Section 9-608 of that Draft was closely patterned on Section 9-319 of the 1992 Annual Meeting Draft.112 ed).

1111992 Annual Meeting Draft, supra note 67, § 9-110(2)(b)(2) (emphasis add-

112 Compare October 1992 Draft, supra note 69, §§ 9-110(2)(b), 9-608, with 1992 Annual Meeting Draft, supra note 67, §§ 9-910, 9-319. 


\subsubsection{Geneva Securities Convention}

Article 12(4) of the GSC provides:

An interest in intermediated securities may be granted under this Article so as to be effective against third parties:

(a)in relation to a securities account (and such an interest extends to all intermediated securities from time to time standing to the credit of the relevant securities account);

(b)in relation to a specified category, quantity, proportion or value of the intermediated securities from time to time standing to the credit of a securities account.

It seems clear enough that an interest in intermediated securities credited to a securities account, as contemplated by subparagraph (a) of Article 12(4), would be a "specified category" of intermediated securities as contemplated by subparagraph (b). However, subparagraph (a) leaves no doubt that it adopts explicitly the SA approach. ${ }^{113}$ As noted in the Official Commentary, Article 12(4) "[i]s in accordance with commercial practices in many jurisdictions[.]" 114

The Restricted Study Group's preliminary draft considered by the First Session of the Committee of Governmental Experts, the November 2004 Draft Convention, also explicitly embraced the SA approach. Article 4(3) of that draft provided: "A security interest created with respect to a securities account under this Article has effect with respect to all securities from time to time credited to that securities account, without the need for any further identification of particular securities."115 The June 2005 Draft Convention

113 However, under Article 12(5)(c), a Conracting State may declare that either or both subparagraphs of Article 12(4) are not applicable and under Article 12(5)(d) that subparagraph (b) applies with modifications. Geneva Securities Convention art. 12(4)(c), (d), Oct. 9, 2009. See HideKI KANDA, ET AL., Official COMMENTARY ON THE UNIDROIT CONVENTION ON SUBSTANTIVE RULES FOR INTERMEDIATED SECURITIES 81 (2012) [hereinafter OFFICIAL COMMENTARY] (noting that "[n]ot all jurisdictions are familiar with or may want to include such determinations [as provided in paragraph (4)] of the subject matter of an interest").

114 OFFICIAL COMMENTARY, supra note 113, at 81.

115 November 2004 Draft Convention, supra note 86, art. 4(3). 
contained a similar provision. ${ }^{116}$

\section{OVERVIEW OF PROPOSALS FOR CA-SA APPROACH AND TRANSACTIONAL ROLES OF AGREEMENTS SUPPLEMENTING CONTROL AGREEMENTS}

We have proposed that Japan adopt the CA-SA approach for transfers of interests in book-entry securities governed by the BETA. Under this proposal a transfer of an interest in securities would be effective against third parties if perfected by book-entry (i.e., a book-entry pledge, book-entry jōto tanpo transfer, or other book-entry transfer) under current law or by control. Control would consist of an agreement by the account holder to create the interest and a control agreement entered into among, or binding upon, the account holder/transferor, the relevant intermediary, and the transferee. ${ }^{117}$ Note that this proposal would extend the CA

116 The June 2005 Draft Convention provided:

A security interest may be granted under this Article in terms such that it extends to all intermediated securities from time to time standing to the credit of the relevant securities account or, if the domestic nonConvention law so permits, to a specified category, quantity, proportion or value of such intermediated securities. Such a security interest is effective without the need for further identification of particular securities.

June 2005 Draft Convention, supra note 93, art. 6(3). The concept of the SA approach emerged early in the process. See UNIDROIT, STUDY LXXVIII DOC. 11, SUMMARY REPORT: RESTRICTED STUDY GROUP ON ITEM 1 OF THE PROJECT: HARMONIZED SubSTANTIVE Rules REgarding SECURITIES Held WITH AN INTERMEdiary 6 (2003), http:/ / www.unidroit.org/english/documents/2003/study78/s-78-011-e.pdf

[https://perma.cc/8DXK-L2AC] (proposal for "transfer [of] a securities account without necessarily identifying the securities in the account").

117 We take no position here on whether Japan, in adopting the CA approach, should adopt a negative control approach, a positive control approach, both approaches, or either approach in the alternative. See supra Part 2.1.2. (discussing positive and negative control). We emphasize here the principle rather than the details. However, positive control has the advantage of permitting the transferee to enforce its interest, without relying on the transferor's cooperation, by instructing the intermediary to dispose of securities credited to the securities account. It is unclear, however, whether such an act of enforcement would be permitted without resort to a court-a question that should be answered in any legislation adopting the CA-SA approach. See Souichirou Kozuka \& Naoe Fujisawa, Old Ideas Die Hard?: An Analysis of the 2004 Reformation of Secured Transactions Law in Japan and its Impact on Banking Practices, 31 T. JefFERSON L. REV. 293, 296-97 \& n. 16 (2009) [hereinafter Kozuka \& Fujisawa, Old Ideas] (expressing the view that in general "self help" remedies without resort to a court are not permitted "except in highly exceptional situations," but that a court likely would uphold such self 
approach to security interests, including outright title transfers for security (joto tanpo) and to outright title transfers not for purposes of security. ${ }^{118}$ Under the SA approach advanced here, the securities covered by such an interest perfected by control could, if so agreed by the account holder-transferor, consist of all securities from time to time credited to a securities account and could be described in the agreement of the parties as an interest in the securities account itself. Finally, adoption of the CA-SA approach necessarily would require the enactment of appropriate priority rules and "cut-off" or "takes free" rules for competing interests. ${ }^{119}$

Figure III.1 reflects the alternative methods of transferring effective interests under the BETA and as they would be modified by adoption of the CA approach.

\section{FIGURE III.1 SUMMARY OF METHODS OF TRANSFER}

Type of Transfer

Pledge

Jōto Tanko

Security Interests other than

Jöto Tanko

Other Transfers
Method of Effectiveness

Book-entry by credit to pledgee's pledge sub-account under the BETA

Book entry by credit to transfereecreditor's proprietary sub-account under the BETA

OR

Control agreement

\section{Control Agreement}

Book entry by credit to transferee's proprietary subaccount under the BETA OR

Control agreement

\footnotetext{
help if so agreed by the parties in advance) (citing Saikō Saibansho [Sup. Ct.] Jul. 14, 1998, Hei 7 (o 才), KK Tokyo Mitsubishi Ginko v. Trustee of KK Creative World, 52 (5) SAIKō SAIBANSHO MinjI HANREISHū [MinSHū ] 1261, 1268-69).

118 See infra Part 5.1 (discussing outright transfers perfected by control).

119 See infra Part 5.3 (discussing proposed priority rules).
} 
The concepts of "control" of a security entitlement under the UCC and "control agreement" under the GSC focus narrowly on the right to give and the obligation to obey entitlement orders and instructions, respectively, with respect to securities accounts. ${ }^{120}$ But the parties to an agreement providing for control also may agree to a number of supplemental rights and obligations. For example, a transferee of a security interest in intermediated securities may be entitled to give instructions to an intermediary only following a debtor's default or following the transferee's notification to the intermediary that a default has occurred. Or, an account holder may be entitled to trade and make withdrawals and substitutions with respect to intermediated securities only if no default has occurred and the value of the relevant securities equals or exceeds an agreed borrowing base (such as a ratio between the collateral value and the secured obligations, ensuring a "cushion" of collateral value). Or, the intermediary or the transferee may agree to subordinate its interest to the other's existing or future interest in the securities credited to the securities account. Such supplemental agreements frequently are referred to colloquially as "terms" of a "control agreement," although they do not actually relate to the more narrow agreements that actually serve to confer perfection by control on a transferee.

It is plausible that securities intermediaries in Japan might be hesitant to enter into such supplemental agreements that could expose them to liability to a transferee-at least without being compensated for such risks. Similar concerns were expressed during the process of developing the 1994 Article 8 Revisions, but the conclusion reached then was to leave the matter to the market.121

\footnotetext{
120 See supra Part 2.1

121 See U.C.C. § 8-106(g) (AM. LAW INST. \& UNIF. LAW COMM'N 2014-15) (securities intermediary not required to enter into control agreement even if directed by entitlement holder). Consider the following explanation: [T]he Drafting Committee confronted a particularly important question related to control: What if the securities intermediary refuses to agree to comply with the secured party's (or another purchaser's) instructions? Revised Article 8 answers this question by leaving the subject largely to the parties and the market. If a securities intermediary is unwilling to accede to an entitlement holder's request that it comply with the secured party's instructions, the entitlement holder retains the right and ability to employ a different intermediary who will so agree. Nevertheless, Revised Article 8 makes it clear that a securities intermediary is free to refuse to enter into such an agreement. The Drafting Committee recognized that it would be inappropriate to require by statute that a securities intermediary deal with, take instructions from, or acknowledge the rights of a stranger with whom it has not agreed to deal.
} 
Consider, however, the experience with such supplemental agreements in the United States during the past almost two decades. ${ }^{122}$ For retail customers of broker-dealer intermediaries who wish to obtain credit secured by securities credited to securities accounts, the norm remains to borrow from the customer's intermediary under a (so-called) "margin" lending arrangement. In other contexts, some securities intermediaries in the United States generally have been willing to enter into only "plain vanilla" control agreements that do not involve any such supplemental agreements. For example, the simplest, most straightforward control agreement would provide that the intermediary would obey instructions of the transferee (affirmative control) and would not obey instructions of the account holder (negative control). Some intermediaries resist arrangements under which they would have to comply with instructions from an account holder and from a control agreement beneficiary during the same period. For example, an account holder might be permitted to trade (e.g., buy and sell, but not withdraw or transfer "free" and not against payment) securities until the intermediary receives a notification from the control agreement beneficiary that it has assumed exclusive control-after which time only that beneficiary (not the account holder) would be entitled to give instructions.

For substantial customers in certain large transactions, more elaborate supplemental agreements have been common. Whether an intermediary will agree to assume significant responsibilities in connection with a control agreement arrangement may depend on

Mooney, Rocks \& Schwartz, supra note 51, at 1897 (footnotes omitted).

122 The discussion of supplemental agreements in the text that follows draws on Telephone Interview with Sandra M. Rocks, Counsel, and Penelope L. Christophorou, Counsel, Cleary Gottlieb Steen \& Hamilton LLC (Nov. 12, 2015). Note that it is the experience with agreements supplemental to control agreements under Revised Article 8 (which had become widely enacted by the late 1990s) that is most relevant. The 1977 version of UCC Article 8 permitted perfection of a security interest by mere notification to a debtor's intermediary, even without the intermediary's agreement. See U.C.C., \& 8-321(1), (2) (AM. LAW INST. \& UNIF. LAW $\mathrm{COMM}^{\prime} \mathrm{N}$ 1978) (providing that appropriate transfer results in a perfected security interest). However, this structure was based on the concept of perfection by possession through notification to a bailee in actual possession of collateral. U.C.C., $\S$ 9-305 (AM. LAW INST. \& UNIF. LAW COMM'N 1978) (“. . . the secured party is deemed to have possession from the time the bailee [in possession] receives notification of the secured party's interest."). Many supplemental agreements as envisioned here were suspect under the 1997 version. This was because permitting the debtor access to securities credited to a securities account, such as by permission to trade or withdraw securities, would have jeopardized the secured party's deemed "possession" and consequently the perfected status of a security interest. 
whether the intermediary will be appropriately compensated for its services or responsibilities. Consider, for example, the roles of major custodian banks (intermediaries) in tri-party repo transactions. $^{123}$ In such transactions the custodian may monitor collateral values, select the securities to be the subject of the transactions, and perform other duties. This is a fee-generating product line for such custodians. Of course, before a Japanese intermediary would undertake any such responsibilities it would be necessary for it to comply with all applicable regulatory requirements and to satisfy Japanese regulators that such supplemental agreements would conform to applicable prudential standards.

\section{SECURITY INTERESTS UNDER THE JAPANESE BOOK-ENTRY}

\section{TRANSFER ACT}

Under the BETA an interest in securities can be acquired by an account holder only by book entries in the securities account maintained by an intermediary for the account holder-e.g., by a debit to a transferor's account and a credit to a transferee's account. ${ }^{124}$ The BETA requires an intermediary to maintain a so-called "matched book." The number of units of securities of each issue credited by an intermediary on its books to its account holders must be strictly matched to the identical number of units of that issue in the intermediary's customer account on the books of JASDEC or another intermediary. ${ }^{125}$ (An intermediary normally maintains a securities account with JASDEC or another intermedi-

123 In a tri-party repo transaction the custodian maintains an account for a securities "seller" / funds transferee (typically a dealer) and enters into a control agreement for the benefit of the securities "buyer" / funds transferor. The interest of the "buyer" (whether or not legally characterized as a buyer or the holder of a security interest) is thereby effective (perfected) as against third parties such as creditors of the "seller." Concerning tri-party repo transactions before the 1994 revisions to UCC Article 8, see STIGUM, supra note 54 (explaining the mechanism of tri-party repo transaction).

124 BETA, supra note 3, at arts. 73 (corporate debt securities), 98 (JGBs), \& 140 (corporate equity securities).

125 BETA, supra note 3, at arts. 70 (corporate debt securities), 95 (JGBs), \& 132 (corporate equity securities). The BETA contains detailed provisions to ensure that credits are offset with matching debits to the appropriate accounts. See, e.g., BETA art. 70(3)-(8) (describing book-entry transfer procedures). 
ary. ${ }^{126)}$ The intermediary's account is divided into two subaccounts. ${ }^{127}$ One sub-account reflects the intermediary's "proprietary" or "ownership" holdings of securities, to which securities owned by the intermediary (and not maintained for its account holders) are credited. The other is its "customer" sub-account, to which securities it manages for its account holders are credited. The customer sub-account normally does not identify individual holdings of each account holder but is an aggregated, or "omnibus," account maintained by the intermediary for all of its account holders. The BETA also makes provision for pledges of securities credited to a securities account. ${ }^{28}$ The proprietary sub-account of an intermediary's securities account is further subdivided into two sub-accounts - a "proprietary" or "ownership" sub-account and a "pledge" sub-account. ${ }^{129}$ A securities account of an account holder that is not an intermediary also may be subdivided into a proprietary or ownership sub-account and a pledge sub-account. When securities are pledged to an account holder (including an intermediary) the securities are credited to the pledge sub-account of the account holder's proprietary sub-account.

Ownership of intermediated securities is acquired by a credit to the proprietary or ownership sub-account of an account holder's account and a pledge to an account holder is made effective by a credit to the pledge sub-account of the account holder's securities account. A security interest by way of outright assignment (jōto tanpo) or a title transfer not for purposes of security also can be made effective by credit to the transferee's proprietary or ownership sub-account. A credit to the proprietary sub-account of the securities account of a transferee of title (in a jōto tanpo transfer or other title transfer) is a necessary, as well as a sufficient, step to

126 As to the accounts maintained by an intermediary with JASDEC or another intermediary, see generally Mooney \& Kanda, Core Issues, supra note 9, at 86 \& n. 80 .

127 Our references here and below to sub-accounts are for clarity of exposition and not as precise translations of the term used in the relevant articles of the BETA, which generally refer to an "account." See e.g., BETA, supra note 3, at art. 68 (regulating matters to be entered or recorded in the registry of book-entry transfer accounts).

128 BETA, supra note 3, at arts. 74 (corporate debt securities), 99 (JGBs), \& 141 (corporate equity securities). As to pledges under the BETA, see generally Mooney \& Kanda, Core Issues, supra note 9, at 113-14 (explaining how pledges work under BETA).

129 BETA, supra note 3, at arts. 68(3) (corporate debt securities), 91(3) (JGBs), $\& 129$ (3) (corporate equity securities). 
render the transfer effective against third parties and in the insolvency proceedings of the transferor. ${ }^{130}$ Similarly, a credit to a pledgee's pledge sub-account of a pledgee's securities account is a necessary and sufficient step for the effectiveness of the pledge. ${ }^{131}$ In effect, a credit to a securities account is recognized as a precise analogue of the delivery of a discrete security certificate. A pledgee may choose to have a pledge of shares of stock notified to the issuer or it may choose to remain anonymous (except as to its debtor and its intermediary) in a non-registered pledge. ${ }^{132}$ A pledgee is presumed not to wish a pledge to be registered with the issuer unless it instructs its intermediary to the contrary. ${ }^{133}$ A transferee other than a pledgee also may wish to have the transfer remain unregistered with the issuer, but such a transfer will be registered unless the transferee instructs otherwise. ${ }^{134}$

130 BETA, supra note 3, at arts. 73 (corporate debt securities), 98 (JGBs), 140 (corporate equity securities). See Kinyū torihiki niokeru azukarisisan wo meguru hō ritsumondai kenkyū kai, Kokyakuhogo no Kanten karano Azukarishisan wo Meguru Seido no Arikata, 32 KINYŪ KENKYŪ , no. 4, 2013, at 25, 71-72. By "sufficient" we mean that no other formality or step is required. However, if an order to transfer lacks a valid intent to transfer, as when made by mistake, the resulting credit would not be effective. See, Naofumi Kaneko, Syasaitō no Furikae nikansuru Hōuritsu no Gaiyō, 57 MinjIGEPPō , no. 10, 2002, at 9, 26.

131 BETA, supra note 3, at arts. 74 (corporate debt securities), 99 (JGBs), \& 141 (corporate equity securities). The use of pledge accounts arguably serves as a weak form of public notice that the securities are pledged to the account holder as opposed to being proprietary assets of the account holder. Given the use of jōto tanpo, however, a credit to an account holder's proprietary account does not negate the possibility that the securities actually are held by the account holder as security.

132 See Mooney \& Kanda, Core Issues, supra note 9, at 114 (explaining the options of the creditor).

133 As to pledged securities in a pledgee's pledge account, unless the pledgee requests to be notified to the issuer, the pledgee will remain anonymous, i.e., the pledgor of shares will be reported to the issuer as the shareholder in the normal course. BETA, supra note 3, at art. 151(3).

134 As to securities credited to a transferee's ownership subaccount of its proprietary account in a jōto tanpo transaction, the transferee will be reported to the issuer as the owner, i.e., as the shareholder in the case of shares, unless the transferee requests that its intermediary notify a central securities depositary (e.g., JASDEC), which in turn would notify the issuer, that the transferor is to remain the owner on the issuer's books. BETA, supra note 3, at art. 151(2)(i). 
Figure IV.1 reflects the account and sub-account structure described above.

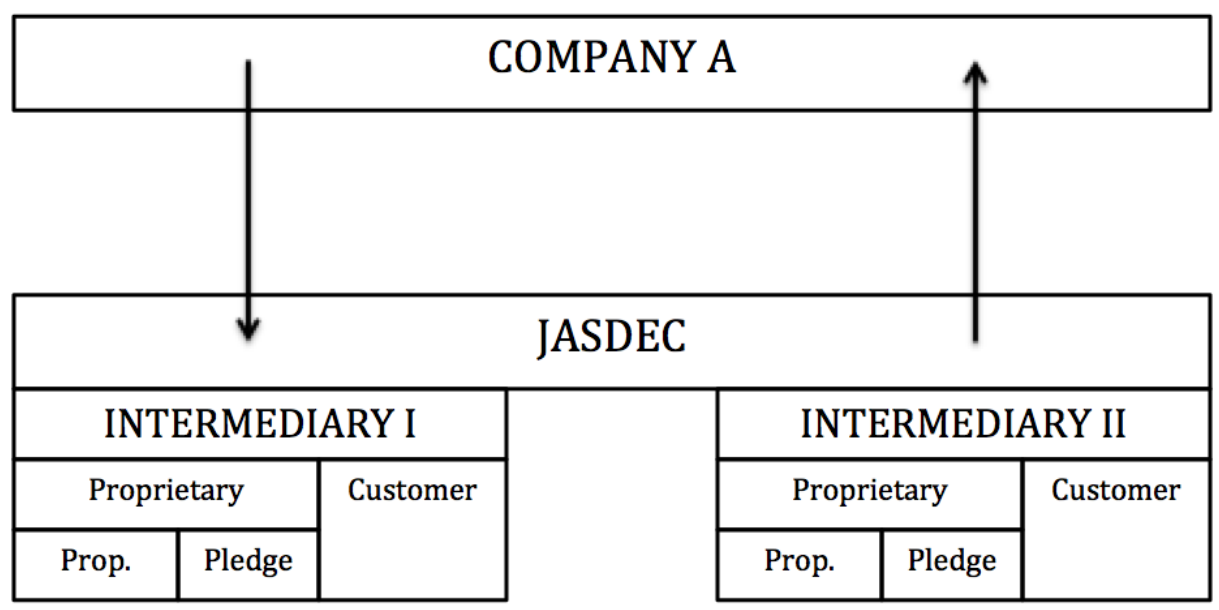

Now consider two examples. In Example 1 Pledgor obtains a loan from Pledgee and Pledgor pledges to Pledgee securities credited to Pledgor's securities account with Broker. In Example 2, Pledgor obtains a loan from Broker and pledges to Broker, as pledgee, the securities credited to Pledgor's securities account with Broker.

EXAMPLE 1. Pledgor borrows $¥ 10$ Million from Pledgee and agrees to pledge 1,000 shares of Company A common stock to secure the loan. Pledgor instructs Broker to transfer the shares to the pledge section of the proprietary securities account of Pledgee with JASDEC. Broker debits Pledgor's account for the 1,000 shares. JASDEC debits Broker's customer account for the shares and credits the pledge section of Pledgee's proprietary account with the shares. 
Example 1 is illustrated by the following graphic:

EXAMPLE 1

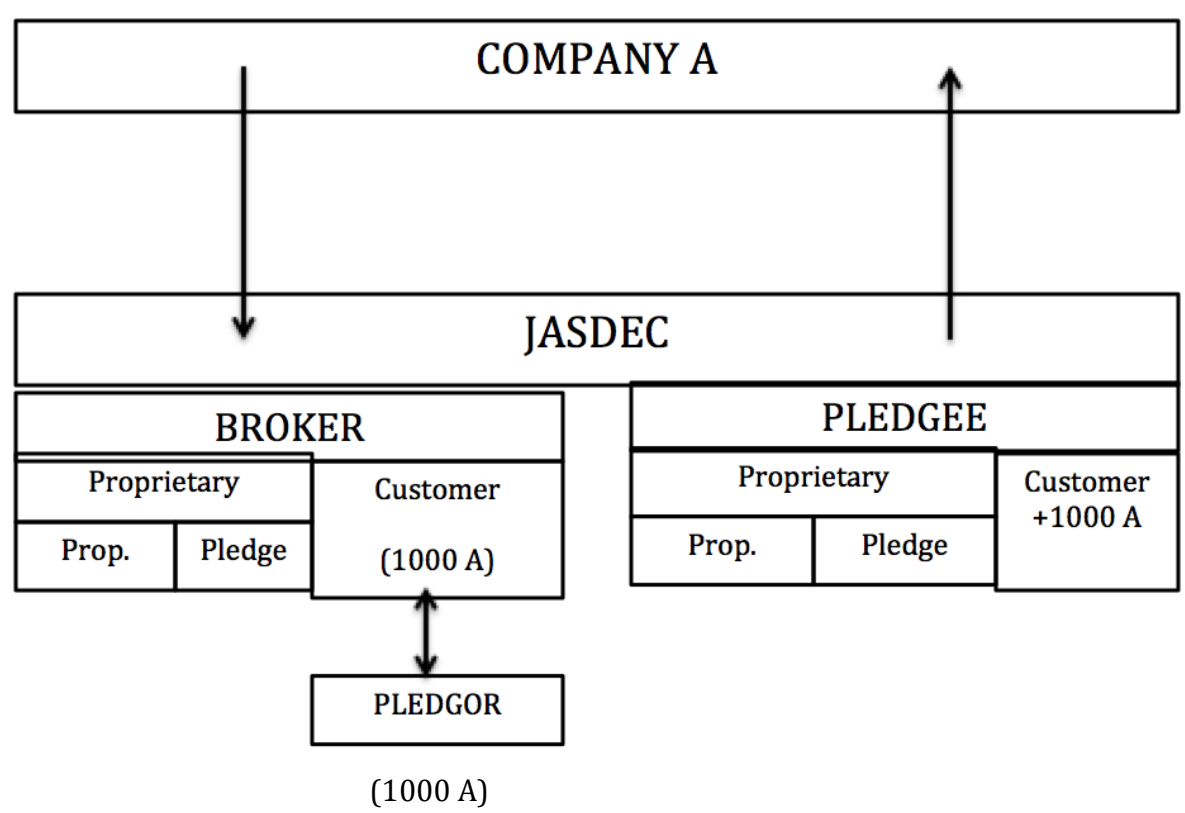

EXAMPLE 2. Pledgor borrows $¥ 10$ Million from Broker and agrees to pledge 1,000 shares of Company A common stock to secure the loan. Pledgor instructs Broker to transfer the shares to the pledge section of the proprietary securities account of Broker with JASDEC. Broker debits Pledgor's account for the 1,000 shares. JASDEC debits Broker's customer account for the shares and credits the pledge section of Broker's proprietary account with the 1,000 shares. 
Example 2 is illustrated by the following graphic:

EXAMPLE 2

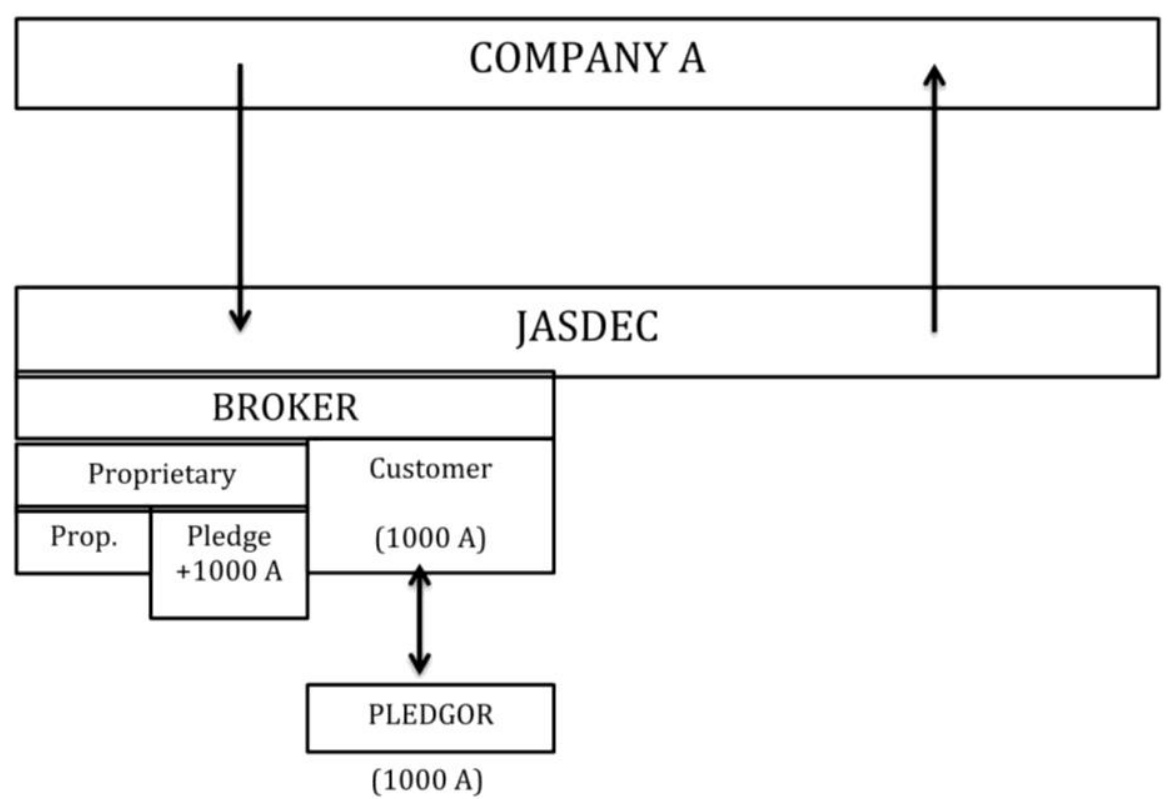

In both Example 1 and Example 2 Pledgee and Broker, the respective pledgees, acquire an effective pledge of the shares. Although Example 1 involves four participants in the pledge transaction, Pledgor, Pledgee, Broker, and JASDEC, Example 2 involves only three participants, Pledgor, Broker, and JASDEC. Both transactional structures are quite straightforward and do not appear to favor or disfavor Pledgor one way or the other in terms of transaction costs or ease of implementation.

It is generally understood that a pledgor retains proprietary rights in certificated securities that are pledged to a pledgee. In the event of insolvency proceedings of a pledgee, the pledgor can resume the clear ownership of certificated securities in the pledgee's possession by discharging the secured obligation. The pledgor is entitled to redeem the pledged securities possessed by the pledgee based on the pledgor's ownership interest. ${ }^{135}$ In the case of a secu-

135 Kinyūtorihiki niokeru azukarisisan wo meguru hō ritsumondai kenkyū kai, supra note 130, at 69; see HASAN Hō [Bankruptcy Act] art. 62 (Right of 
rity interest transferred by means of an outright assignment ( $j \bar{o} t o$ tanpo) as well, the security interest is made effective by the pledgor's delivery of the certificated securities to the pledgee. ${ }^{136}$ Even though structured as an outright assignment of title, jōto tanpo is generally recognized as a secured transaction and is treated as such. ${ }^{137}$ Accordingly, the commencement of a transferee's insolvency proceeding (before a secured obligation's maturity) may not affect the relationship between the transferor and transferee. As with the possessory pledge discussed above, in the case of a joto tanpo transaction the transferor retains a proprietary right in the certificated securities. In the event of the transferee's insolvency, the transferor could assert its right of redemption as to certificated securities by discharging the secured obligation. ${ }^{138}$

Under the BETA the book entry is the fundamental concept that underpins the system. It is the basis for the entire legal framework for establishing the rights of an account holder and the effectiveness of transfers of interests in book-entry securities. As mentioned above, ${ }^{139}$ an interest in book-entry securities can be acquired only by a book entry to an account holder's securities account maintained by an intermediary. Consistent with this fundamental concept, the effectiveness of a pledge or other transfer of an interest in book-entry securities also requires a credit to the pledgee's or other transferee's securities account (either in the pledge section or, in the case of a jōto tanpo outright assignment,

Segregation) (providing that the commencement of bankruptcy proceeding does not affect the right of segregation).

136 For corporate shares, see Kaisha-Hō [Companies Act], Act No. 86 of 2005, art. 128(1) ("Transfer of shares in a Company Issuing Share Certificate shall not become effective unless the share certificates representing such shares are delivered; provided, however, that this shall not apply to transfer of shares that arise out of the disposition of Treasury Shares.").

137 HiROTO Dō GAUCHI, TANPOBUKKENHō 298-302 (3d ed. 2008).

138 See id. (discussing right of redemption with respect to assets generally); Denshitekikiroku ni motozuku kenri wo meguru hō ritsumondai kenkyū kai, Furikaeshōken/Denshikirokusaiken no D̄̄nyū wo Fumaeta Hōkaishakuron no Saikentō, 34 KINYŪ KENKYŪ , no.3, 2015, at 1, 21-27 (discussing right of redemption with respect to assets generally as well as securities). We are not aware of a reported decision dealing the right of redemption with respect to certificated securities. There are arguments for imposing "perfection" requirements on a transferor's right of redemption in a jo to tanpo transaction as against a creditor of the transferee that has attarhed the transferred asset. Saikō Saibansho [Sup. Ct.] Oct. 20, 2006, Hei 18 (ju 受) no. 1641, 60 SAIKō SAIBANSHO MinjI HANREISHŪ [MINSHū] 3098 (Japan); see MAKOto Ito, HasAnHō / Minjisaiseihō 451 (3d ed. 2014).

139 See supra note 124 and accompanying text. 
the proprietary section). It is clear that a pledgor retains proprietary rights in securities pledged in the BETA book-entry system and credited to a pledgee's pledge section and a corresponding right of redemption in the pledgee's insolvency proceeding. However, it is not clear whether a transferor in a jo to tanpo transaction in the BETA system would retain proprietary rights and a right of redemption. ${ }^{140}$ In the absence of such proprietary rights the joto tanpo transferor would have only a personal, unsecured claim in the jo to tanpo transferee's insolvency proceedings. While a definitive analysis of this issue is beyond the scope of this paper, it is significant that adoption of the CA approach through clear statutory provisions would eliminate this jōto tampo transferee insolvency risk for jōto tanpo transferors in the BETA book-entry system. ${ }^{141}$ Now consider application of the CA approach in the context of the jōto tanpo transferee's insolvency in a situation similar to Example 1.

EXAMPLE 3. Transferor borrows $¥ 10$ Million from Transferee and agrees to transfer in a jōto tanpo transaction 1,000 shares of Company A common stock to secure the loan. Transferor, Transferee, and Broker conclude a control agreement covering the 1,000 shares credited to Pledgor's account with Broker. The parties agree that the 1,000 shares are to remain credited to Transferor's account and that Transferor is free to dispose of other securities credited to the account. Following the commencement of Transferee's insolvency proceeding, Transferor pays to Transferee (or Transferee's insolvency representative) the secured obligation. The 1,000 shares remain credited to Transferor's account, over which neither Transferee nor Transferee's insolvency representative retains any right or interest because the secured obligation has been discharged.

140 See Denshitekikiroku ni motozuku kenri wo meguru hō ritsumonndai kenkyū kai, supra note 138, at 27-31 (discussing jōto tanpo in connection with jōto tanpo transferee's proprietary account and requirements for asserting the right of redemption, especially the difficulty of identifying securities in the book-entry system).

141 See id. and accompanying text. We do not intend to overemphasize this point, inasmuch as we understand that the issue has not been the subject of litigated disputes. However, providing additional certainty and predictability in secured transactions law could only have beneficial effects at the margin. 


\section{PROPOSED REVISIONS OF JAPANESE BOOK ENTRY TRANSFER}

\section{ACT: POLICY ANALYSIS}

In this Part we evaluate the merits of our proposal that Japanese law incorporate the CA-SA approach under the BETA.

\subsection{Conceptual Consistency of Proposal with Book Entry Transfer Act and Traditional Japanese Property Law}

As explained in Part 4 with respect to certificated securities, a pledgor or transferor in a jōto tanpo transaction retains a proprietary (ownership) interest in certificated securities, and a right of redemption by discharging the secured obligation, even after the pledgor's or jōto tanpo transferor's delivery of possession of the securities to a pledgee or jōto tanpo transferee. While it is unclear, a jōto tanpo transferor may retain such a proprietary interest and right of redemption with respect to book-entry securities even after the transferor's account has been debited for the transferred securities (thereby removing the securities from the jōto tanpo transferor's account) and the jōto tanpo transferee's proprietary account has been credited with the securities. ${ }^{142}$ If the $j \bar{o}$ to tanpo transferor does retain such an interest and right, then the BETA would already recognize that one entity can hold a beneficial interest for another entity and that one book entry can suffice as evidence for limited interests of two entities. Thus, the unitary concept of BETA, which embraces a unitary method of original acquisition solely by book-entry in favor of a single account holder, ${ }^{143}$ could co-exist with the jōto tanpo structure. It already does under the pledge account structure, under which a jōto tanpo transferee holds through its intermediary both for itself as well as for the jōto tanpo transferor.

142 See supra note 123 and accompanying text. While the pledgor's retention of a proprietary interest is generally accepted, as noted in Part 4, there is some question as to whether a transferor retains such a proprietary interest in the insolvency proceedings of an outright transferee in a jōto tanpo transaction.

143 See Mooney \& Kanda, Core Issues, supra note 9, at 114 (providing an overview of the operation and functions of the BETA). 
If the conceptual aspect of securities holding for jōto tanpo transfers under the BETA was recognized, it also would become apparent that there is no conceptual inconsistency between the BETA's core principles and the CA-SA approach. Under CA-SA an intermediary would recognize that securities credited to a transferor's account with the intermediary are also held by the intermediary for the benefit of a transferee pursuant to the intermediary's control agreement. In this way the BETA could accommodate a situation in which an intermediary holds for more than one beneficiary.

Consider the CA-SA approach and the BETA from a functional perspective. Under the BETA the account holder is the sole holder of a property interest in book-entry securities to the exclusion of the intermediary and all other persons. But it is the intermediary that has the power (even if not the right) to transfer the book-entry securities (such as by giving a transfer instruction to JASDEC, the intermediary's (in its position as account holder) relevant intermediary). Under the CA-SA approach, the account holder would retain its property interest in book-entry securities (subject to a transferee's security interest), but the transferee (under an affirmative control structure) would, like an intermediary under the BETA, have the power to transfer the book-entry securities by instruction to the relevant intermediary.

The CA-SA approach also may be viewed from the perspective of the integrity and reliability of records. Given the nature of entities qualified to act a securities intermediaries in Japan, ${ }^{144}$ there is no reason to think that the evidence and details of an intermediary's control agreement would be any less reliable than its records concerning book entries. Indeed, the core principle of the bookentry system is its reliance on intermediaries to maintain records of securities accounts accurately and honestly. Moving to the CA ap-

144 Financial Instruments and Exchange Act (FIEA), Act No. 25 of 1948, as amended in 2006 (Act 65 of 2006) (changing title from "Securities and Exchange Act" to "Financial Instruments and Exchange Act"), and as amended through 2014 (Act No. 91 of 2014), art. 2(8)(xvii) (stating that the conduct of "Financial Instruments Business" includes acting as an intermediary for securities accounts under the BETA); FIEA, art. 29 (registration); FIEA, Enforcement Ordinance, art. 15-7(1) (minimum capital); FIEA, art. 46-6(1) (capital-to-risk-ratio) (stating that such activity is a "Type I Financial Instruments Business" and such an intermediary is required to be registered with the Prime Minister and to meet minimum capital requirements and a capital-to-risk-ratio requirement); FIEA, art. 43-2(1) (dictating that such an intermediary also must manage securities separately from ists own property in accordance with an approved method). 
proach would depend on the reliability of intermediary records no more and no less than under the current book-entry approach. Similarly, from the perspective of public notice, there would be no material difference between a book-entry transfer and perfection by a control agreement-neither would be readily available to the public except as disclosed by the pledgor or other transferor (account holder) or, with the pledgor's or other transferor's authorization, by its intermediary. ${ }^{145}$ It follows that any objection to the CA approach based on the absence of public notice would not be persuasive. Whatever benefits public notice requirements (such as the UCC filing regime and other registration regimes) provide in other contexts, the very existence of an account holder's interest in bookentry securities and in its securities account is inherently secret. A public notice-based objection to the CA approach would apply equally to book entries or to an account holder's specification of the persons authorized to give instructions with respect to a securities account-an inherent aspect of any system for intermediated securities. However, it would be entirely appropriate for Japan to provide for public filing or registration as an alternative perfection method in addition to perfection by book entry or control agreement. 146

145 A book-entry pledge would be reflected by a debit to a pledgor's account statement or, on an interim basis, in the account records as a reduction of a pledgor's holdings. A control agreement would not so appear. However, even a third party with access to the account statement or records could fully rely on such records inasmuch as they provide only a snapshot at a particular time and date. Subsequent withdrawals or other transfers could have been made. The same comparison as between a control agreement and a designating entry in the account records would hold with respect to account statements. See GSC art. 12(1), (3)(b) (dictating that grant of an interest in intermediated securities is made effective against third parties by designating entry); $1(1)$ (defining "designating entry"). Of course, if it were thought to be necessary or useful, adoption of the CA approach under Japanese law could be accompanied by a requirement that intermediaries make corresponding designated entries in the account records. Alternatively, another method of official recordkeeping of control agreements could be imposed on intermediaries, such as notifications to JASDEC (perhaps pursuant to JASDEC regulations). Also, a requirement that a control agreement bear a date certification (kakutei hizuke), such as a date stamp by a Japanese notary, could be imposed.

146 See, e.g., U.C.C. § 9-312(a) (AM. LAW INST. \& UNIF. LAW COMM'N 1977) (stating that perfection of security interest in investment property is created by filing). Perfection by control offers the benefit to a creditor of depriving the transferor of power over the securities (negative control) or providing such power to the transferee (affirmative control). Perfection by book-entry also offers the practical benefits of negative and positive control. While permitting perfection by registration or public notice could provide even greater flexibility to parties, an examination of 
Note as well that the CA approach also is conceptually consistent with traditional aspects of Japanese property law. For example, if an agent were in physical possession of movables on behalf of its principal, it could deliver the movables to a third party transferee by instruction from its principal without any actual change of possession - a step analogous to an intermediary entering into a control agreement for the benefit of the third-party transferee. ${ }^{147}$ Although the agent would hold actual physical possession, the third party transferee also would have possession as a result of such a delivery. From a functional perspective, both an agent in possession of movables and a third party transferee (resulting from an instruction to the agent) would possess the power to transfer the movables to the exclusion of the principal/transferor. Under the CA approach, the transferee likewise would acquire such power under an affirmative control arrangement.

Japanese law on the assignment of a nominative (money) claim under Minpō articles 467 and 364 provides another apt example. Such an assignment involves an obligor, an obligee/assignor, and an assignee. Article 467(1) provides that an assignment is not effective as against the obligor or any third party "unless the assignor gives a notice thereof to the obligor or the obligor has acknowledged the same."148 Moreover, article 467(2) provides that the assignment is not effective "against a third party other than the obligor unless the notice or acknowledgement is made using an in-

the benefits of perfection by registration or public notice is beyond the scope of this article.

147 See MinPō [Civil Code] art. 184 ("In cases where a Thing is in an agent's possession, if the principal orders that agent to thenceforward possess that Thing on behalf of a third party, and such third party consents thereto, that third party shall acquire possessory rights."); art. 183 ("If an agent manifests an intention that The thing possessed by it shall thenceforward be possessed on behalf of its principal, the principal shall thereby acquire possessory rights.") (providing other examples of a transfer of possessory rights in the absenceof an actual transfer of possession to a transferee); art. 181 ("Possessory rights may be acquired by an agent."); art. 182 ("(1) The transfers of possessory rights shall be effected by the delivery of the Thing possessed. (2) In cases where a transferee or his/her agent actually holds a Thing, the transfers of possessory rights may be effected by the parties' manifestations of intention alone."); see also Charles W. Mooney, Jr. \& Atsushi Kinami, Transfer, Pledge, Clearance and Settlement in the Japanese and United States Government Securities Markets, 12 U. Pa. J. Int'1 Bus. L. 517, 537-42 (1991) (drawing parallels between United States and Japanese law).

148 Minpō [Civil Code] art. 467(1). 
strument bearing a fixed date."149 Such a notice or acknowledgement pursuant to article 467 also is necessary for a pledge over a nominative claim to be effective as against third parties. ${ }^{150} \mathrm{~A}$ securities intermediary is analogous to an obligor on a claim, given its duties to its account holders. An account holder's transfer of an interest in securities credited to its securities account (or to the account itself) likewise is analogous to an assignment of a claim. Clearly, then, an intermediary's entering into a control agreement is analogous to an obligor's acknowledgement of an assignment of a claim. Again, the CA approach is conceptually consistent with Japanese property law. On the other hand, neither the Minpō approach nor the CA approach reflects an optimal system for perfection of assignments of claims (receivables). A transferor typically would have only a small number of securities accounts that, once established, would be maintained and used over a substantial period of time, thus making the CA approach feasible. But a typical transferor of receivables typically would own many (hundreds or thousands) of receivables, many of which could be of a relatively short term between creation and the maturity date (e.g., thirty days). In that context, requiring a notification to or an acknowledgment by every obligor on the assigned receivables would be cumbersome and wholly impractical. Perfection by registration or public notice would be preferable. ${ }^{151}$

It generally has been understood that an actual delivery of certificated securities is required for a transfer to be effective. ${ }^{152}$ In particular, the Companies Act specifically so provides with respect

149 MinPō [Civil Code] art. 467(2).

150 Minpō [Civil Code] art. 364.

151 See PRAMC, supra note 27, art. 4(1) (providing that registration of an assignment of a claim in the claim assignment registration file constitutes the equivalent of a notice to all third parties other than the obligor made with an instrument bearing a fixed date for purposes of Minpō art. 467(2)). While registration of an assignment of claims certainly is less burdensome than actually notifying each obligor, in the case of the assignment of existing outstanding claims it remains necessary under the PRAMC to include in the registration a description of the assigned claims that identies obligors by name. Registry Rules for the Assignment of Movables and Claims, Ministry of Justice Ordinance No. 99 (2005) Art. 9(2); see U.C.C. § 9-504, cmt. 2 (AM. LAW INST. \& UNIF. LAW COMM'N 1977) (stating that under the UCC, however, it would be possible to perfect an assignment of receivables by filing a financing statement covering, e.g., "all of debtor's receivables now existing or hereafter arising.")

152 This is so notwithstanding that "[a] bearer certificate of claims is deemed to be movable." MinPō [Civil Code] art. 83(3). 
to share certificates. ${ }^{153}$ However, as described above, 154 it is a bookentry that effects transfer of uncertificated, book-entry securities under the BETA. ${ }^{155}$ Even before enactment of the Securities Depository Act, 156 the BETA's predecessor, it was strongly argued that an actual delivery of certificated securities should not be an absolute requirement for a transfer to be effective because there was no such legislative base for such a requirement.157 Other methods of transferring possession, such as an instruction by a principal, necessarily should be permitted in order to respond to practical reality and necessity. ${ }^{158}$ This argument is consistent with requiring instructions to intermediaries as a condition for effective transfers in the book-entry system. For book entries to replace actual deliveries in the book-entry system, the intermediaries must play a key role. As described above, it is a book entry that effects a transfer of uncertificated, book-entry securities under the BETA and the power to make such transfers lies with the intermediaries.

In general, a certificated security has been understood as a device for attaching invisible "rights" to a visible piece of paper in order to make the rights suitable for trading. The law of certificated securities (the law of negotiable instruments included) regulates parties' rights and obligations in accordance with the location or possession of the certificated securities in order to make legal relationships certain and clear. It follows that the law requires an actual delivery of a certificate for a transfer to be effective, as explained above. A possessor of a certificate is an owner unless proved oth-

153 Kaisha-Hō Companies Act, Act No. 86 of 2005, art. 128(1) (“Transfer of shares in a Company Issuing Share Certificate shall not become effective unless the share certificates representing such shares are delivered; provided, however, that this shall not apply to transfer of shares that arise out of the disposition of Treasury Shares."); Id. arts. 687 (corporate debt securities), 255(1) (share options) (stating that there are similar provisions for corporaate debt securities and share options).

154 See supra Part 4.

155 Before the BETA was enacted and effective this was also the case for certificated securities held with JASDEC. Law Concerning Deposit and Transfer of Stock Certificates and Similar Certificates, Law No. 30 of 1984 [hereinafter Securities Depository Act] art. 27(2) (providing that book entries on the books of JASDEC or on the books of JASDEC participants are adequate to effect deliveries of certificates).

156 Id.

157 Id. at 9.

158 Id. at 8-9; see MinPō [Civil Code] arts. 183, 184 (detailing the law on constructive transfers and transfers of possession). 
erwise. ${ }^{159}$ However, with investment securities being traded in enormous volumes even as early as the 1960s in Japan, it was recognized that a requirement of an actual delivery would be very inconvenient, even unrealistic. The practice emerged for securities firms to keep possession of certificated securities for their customers; the firms did not deliver the certificates to their customers but instead declared themselves as agents for acquiring possessory rights for their customers. ${ }^{160}$

The securities firms holding possession of certificated securities for their customers kept records of holdings and transfers of securities credited to customers' accounts while the certificated securities themselves were deposited and never moved.161 In the book-entry system, a core issue is the effect of book entries. The Securities Depository Act ${ }^{162}$ provided that an account holder was deemed to have "possession of certificated securities" credited by book entry to an account holder's account, thus equating a book entry with certificated securities. ${ }^{163}$ Accordingly, a credit to an account was deemed to be an "actual delivery" of certificated securities. ${ }^{164}$ The basic legal concepts and framework for certificated securities, such as protection for innocent acquirers, were thereby incorporated into the new system for the protection of customers. 165 Moreover, Article 26 of the Securities Depository Act provided that "a customer [an account holder] should make an application to transfer the securities in his/her account to others."166

To be sure, revising the BETA to incorporate the CA-SA approach would modify the current structure of the BETA for security interests, including jōto tampo transfers, and other outright trans-

159 See Companies Act art. 131(1) (“A possessor of share certificates shall be presumed to the the lawful owner of the rights in relation to the shares representing such share certificates.").

(1969).

161 Id. at 9-10.

162 BETA, Supp. art. 2 (1984); The Securities Depository Act was repealed and replaced by the BETA.

163 Securities Depository Act art.27(1).

164 Securities Depository Act art.27(2).

165 Ichiro Kawamoto, Kabuken Hokan Furikae Hō, in 4 SHINPAN CHŪ SHAKU KAISHA Hō 319 (Katsuro Ueyanagi, Tsuneo Otori \& Akio Takeuchi eds., 1986).

166 Securities Depository Act art. 26; see ICHIRO KAWAMOTO, supra note 160, at 312 (stating that the art. 26 of the Securities Depository Act was analyzed as a formal requirement of a transfer of possession by Minpō Article 184 within the book-entry system under the Securities Depository Act). 
fers - it would permit an effective security interest or other transfer of an interest in the absence of a book-entry in favor of the transferee. But the foregoing discussion demonstrates that such a move would not represent a radical change from the perspectives of delivery of possession (or its equivalent), property law, or function. A delivery or its equivalent with respect to movables, claims, or securities is effective under the Minpō and the BETA through communications or records - orders or declarations (movables), notices or acknowledgments and instruments (claims), and book entries (securities). In each case the needs of parties are taken into account and the relevant transactional settings are accommodated. Adopting the CA-SA approach for securities would be an incremental adjustment that the BETA easily could accommodate-a transfer made effective by a communication and record, i.e. a control agreement. In our view, adoption of such a revision of the BETA should be based on a policy analysis, discussed below in Part 5.2., and Japanese property law concepts do not provide any bases for rejecting the CA-SA approach.

While we are not analyzing here the suggestion to recognize nominee holding under Japanese law, it is at least worth noting that recognition of nominee holding also would be entirely consistent with the structure and concepts underlying the BETA. An intermediary would credit the account of a single account holder to which its duties would be owed and which would be entitled to instruct the intermediary. The BETA regime and the relevant intermediary would not be required in any manner to take account of the fact that the account holder might be holding for an unidentified beneficial owner. The principal effects of recognizing nominee holding would be the effectiveness of the beneficial owner's rights and interest vis-à-vis creditors and the insolvency representative of the nominee holder. ${ }^{167}$

Finally, the CA approach easily could be applied to make effective (perfect) security interests, including outright transfers for security (jōto tanpo), and other outright transfers, such as sales and resales pursuant to repo transactions. In this connection, we acknowledge that there may be a certain awkwardness in recognizing the effectiveness of an outright transfer while the book-entry

167 Of course, a nominee should not be permitted to use its status as such to function as a de facto intermediary for account holders in order to evade the applicable regulatory regime. See supra note 143 (discussing requirements and qualifications for acting as an intermediary for securities accounts under the BETA). 
securities remain credited to the securities account of the transferor. On reflection, however, this approach is no more awkward than recognizing the transfer of possessory rights in movables under the Minpō even in the absence of any change in actual possession. ${ }^{168}$ As between the parties, and as between the parties and third parties, the point of the CA approach is to provide a reliable basis for determining the securities being transferred and the effectiveness of the transfer as it relates to third parties. Along those lines, the extent and nature of the interest being transferred would be a matter of proof in the event of any dispute or in the context of enforcement.

\subsection{Perfection by Control Agreement and Security Interests in Securities Accounts}

Turning first to the BETA's current approach to pledges, it is useful to consider what benefits might be achieved by the requirement that an effective pledge be carried out by book entries that cause particular categories and quantities of securities to be credited to the securities account of the pledgee-book-entry pledges. The most obvious attribute of a book-entry pledge of dematerialized securities is that it is the closest analogue of a traditional possessory pledge in which physical possession of a pledgor's security certificate is delivered to the pledgee. As with a physical pledge, a book-entry pledge removes the securities entirely from the reach of the pledgor (by debit to and removal from its account) and confers on the pledgee (by credit to its account) all power and domain over the securities. Functionally and more specifically, the pledgee's power derives from its right to instruct its own intermediary with respect to the pledged securities credited to the pledgee's account and the resulting inability of the pledgor to so instruct the pledgee's intermediary.

Substantially the same result that occurs thorough a bookentry pledge (or through a book-entry jōto tanpo transfer or other outright transfer effected by a book entry) could be achieved by the use of a control agreement. Assume that a transferor, the transferor's intermediary, and the transferee enter into a control agreement with respect to an identified quantity of specified issues of securi-

168 See supra note 146 (explaining perfection by control). 
ties credited to the transferor's securities account. Under the control agreement the pledgor's intermediary agrees to obey only the instructions of the transferee (positive control) and not to obey any instructions of the transferor (negative control). This achieves the result that the transferee, but not the transferor, has complete power over the transferred securities. This is the same result that would occur pursuant to a book-entry transfer, but without the need to involve the securities accounts of the transferor and transferee and the transferee's intermediary. ${ }^{169}$ From the perspective of the transferor's intermediary, pursuant to the terms of the control agreement it knows whose instructions to obey - those of the transferee. From an operational perspective the impact of such a control agreement would be essentially the same as if the transferor had instructed its intermediary that employee $X$ is no longer authorized go give instructions in connection with the account and that going forward employee $Y$ would give instructions. Adopting a CA feature would in no manner disrupt the intermediated holding apparatus under the BETA and would preserve the principal benefits of book-entry transfers.

In the case of a jōto tanpo transaction, in addition to eliminating the need to involve the transferee's intermediary in the transaction, a CA perfection feature would provide additional benefits. In particular, because the securities covered by a control agreement would not be credited to the transferee's securities account, but would remain in the transferor's account, the risks and uncertainties in the case of the jōto tanpo transferee's insolvency proceeding would be ameliorated. 170

In one respect the use of a CA perfected transfer could marginally increase transaction costs because it would be necessary for the transferee to negotiate with the transferor's intermediary over the terms of the control agreement. In its simplest form, when the agreement would be to confer on the transferee the exclusive right to give instructions, these costs might be minimal. The costs could

169 Adopting a CA feature would not preclude the use of book-entry pledges. For example, a pledgee may wish to have the securities credited to its own account with its own intermediary inasmuch as it may not be comfortable with the pledgor's intermediary. While this reflects the wisdom of preserving book-entry pledges, it does not provide any support for rejecting the CA approach.

170 See supra notes 139-40 and accompanying text (discussing jōto tanpo transferee's insolvency in the context of jōto tanpo book-entry transfers). However, the advantage that a CA feature could offer in this context would not eliminate the long-term need to clarify this aspect of the status of jōto tanpo book-entry transfers, which would remain much in need of reform. 
be considerably more if there were extensive supplemental agreements (e.g., maintaining a collateral value cushion, permitting transferor to withdraw or trade absent default, etc. ${ }^{171}$ ). On the other hand, even in connection with a book-entry pledge it would be necessary for the pledgor and pledgee inter se to negotiate (and presumably reduce to writing) any such supplemental agreements.

Even greater benefits could be achieved were CA perfection to be complemented by providing for the non-book-entry security interests, including jo to tanpo transfers, and non- jōto tanpo outright transfers to cover a debtor's or other transferor's entire securities account (i.e., all securities from time to time credited to the account, the CA-SA approach) as opposed to discrete quantities of specified issues of securities. Consider the following example.

EXAMPLE 4. At Time 1 (T-1) Pledgor pledged to Pledgee, by way of book-entry pledge under the BETA, 100 shares of A Company common stock and $¥ 1$ Million face amount of B Company bonds. The combined market value of the stock and bonds was $¥ 2$ Million. These securities were transferred and credited to Pledgee's pledge account at JASDEC and Pledgee is Pledgor's intermediary (this is the same transactional structure as in Example 2). The securities secure a loan with an outstanding principal balance of $¥$ $1,500,000$. Under the applicable loan agreement, Pledgor is required to maintain at all times for the benefit of Pledgee effectively pledged securities of a market value not less than $125 \%$ of the outstanding principal balance of the loan (the "borrowing base"). Failure to maintain this collateral cushion is a default. The value of the A Co. shares declined precipitously as a result of the disclosure of unfavorable financial information. At T-2 the combined market value of the collateral was $¥ 1,300,000$, far below the required minimum value of $¥ 1,875,000(125 \%$ of $¥ 1,500,000)$. Although there are securities of ample value credited to Pledgor's securities account maintained with Pledgee, as intermediary, only the A Co. and B Co. securities are credited to Pledgee's pledge account at JASDEC. At T-2 Pledgor fails to transfer additional securities to Pledgor's pledge account notwithstanding Pledgee's demand on that date. Before Pledgee

171 See supra Part 3. (discussing such supplemental agreements). 
could seek judicial assistance, Pledgor withdrew the remaining securities (i.e., those that have not been transferred to Pledgee's pledge account) from its securities account with Pledgee.

Pledgee might have insisted, as an original condition of the loan, that all of the securities credited to Pledgor's securities account be transferred to Pledgee's pledge account (an admittedly unlikely situation). Had Pledgor agreed to that term, the value of the securities credited to Pledgee's pledge account then would have far exceeded the agreed borrowing base. Moreover, that approach might have imposed administrative and record-keeping burdens for Pledgor's trading activities with securities in excess of borrowing base.

EXAMPLE 5. Now vary Example 4 by assuming that Pledgee is not Pledgor's intermediary but instead is a thirdparty lender (this is the same transactional structure as in Example 1). Assume further that Pledgor (unlikely as it might seem) acceded to Pledgee's (unlikely) demand that all of the securities credited to Pledgor's account with its intermediary be transferred to Pledgee's pledge account with JASDEC. That scenario would be quite cumbersome for Pledgor to engage in trading or other dispositions with respect to excess securities-necessitating transfers from Pledgee's JASDEC pledge account to Pledgor's account with its intermediary in advance of Pledgor's subsequent trades or other onward transfers.

A central insight here with respect to a security interest in or other transfer of an interest in a securities account is the same as that for CA perfection - a book entry would not be a necessary step for an effective security interest or other transfer. A further insight for a security interest or other transfer of a securities account is that the security interest or other transfer need not be on a security issue-by-security issue basis. It would be sufficient that the account holder agrees that the transferee will acquire its interest in all securities from time to time credited to the securities account and that the security interest or other transfer will be so effective as long as such securities remain credited to the account. The CA-SA ap- 
proach combines these insights and would allow a transferee to acquire an interest in securities at any time credited to a securities account and to perfect the interest pursuant to a single control agreement among the account holder-transferor, the transferee, and the relevant intermediary. ${ }^{172}$ We can think of no sound policy reason why an account holder should be prohibited from establishing such an arrangement in favor of a transferee. (Of course, one must keep in mind that a holder of a security interest would not be entitled to recover more than the secured obligation owed to it.) It follows that there is no justification for an intermediated securities legal regime to require pointless and unnecessary steps - i.e., discrete book entries for each issue and quantity of securities involved - to create such an effective pledge or other transfer.

Revising the BETA to embrace the CA-SA approach would have met the needs of both Pledgor and Pledgee in Examples 4 and 5. Unlike under a book-entry pledge arrangement contemplated in those examples, the debtor-transferor would have been free to trade and withdraw securities from time to time so long as the borrowing base value had been maintained. The debtor would not have been inconvenienced (or worse) by the cumbersome requirement that excess securities be moved out of the Pledgee's account (had that been the arrangement) and back into Pledgor's account. The creditor-transferee would not have suffered the diminution of its borrowing base as a result of the cumbersome requirement of a book-entry pledge (moving securities into its pledge account), the debtor's failure to cooperate, and the debtor's withdrawal of its excess securities.

Adoption of the CA-SA approach for the BETA would be in the mainstream of modern secured transactions laws that embrace the "floating lien" concept. This approach is particularly important for collateral that turns over, such as inventory and receivables, and is a cornerstone of UCC Article 9,173 the UNCITRAL Legisla-

172 Of course, as discussed above a control agreement would not be necessary when the transferor's intermediary is the transferee. See supra note 19. It would only be necessary for the parties to agree on the circumstances, if any, under which the transferor would have a continued right to instruct the intermediary-transferee in connection with trading or withdrawals.

173 U.C.C. § 9-204(a) (AM. LAW INST. \& UNIF. LAW COMM'N 2000) ("a security agreement may create or provide for a security interest in after-acquired collateral"). Comment 2 to UCC section 9-204 provides, in pertinent part:

This section adopts the principle of a "continuing general lien" or "floating lien." It validates a security interest in the debtor's existing and (upon acquisition) future assets, even though the debtor has liberty to use or dispose of collateral with- 
tive Guide,174 and the draft UNCITRAL Model Law on Secured Transactions. ${ }^{175}$ If this approach to secured financing of receivables and inventory makes sense, and we believe it does, then it should make just as much sense for security interests and other transfers of interests in book-entry securities. It is not surprising, then, that the CA-SA approach also has been adopted by the Geneva Securities Convention as an alternative available to a Contracting State by declaration ${ }^{176}$ as well as by UCC Articles 8 and $9 .{ }^{177}$ Finally, it is worth noting that the SA approach reflects a more important, fundamental aspect of a modern secured transactions law than does the CA approach. It embodies the core concept of a floating lien over after-acquired property. It is the SA approach in particular that would be likely to reduce transaction costs and increase the certainty and flexibility in secured transactions. ${ }^{178}$ But adopting the SA approach (whether as a part of a generally applicable secured transactions law, as revisions to the BETA, or otherwise) necessarily would require the adoption of a perfection method other than a book entry-such as the CA approach, filing or registration in a public registry, or even automatic perfection without any further steps.

To reiterate and for the same reasons discussed above in connection with the CA approach, ${ }^{179}$ the SA approach easily could be extended beyond security interests and applied to outright title transfers. The GSC has embraced the SA approach for all transfers not involving a credit to a securities account. ${ }^{180}$

out being required to account for proceeds or substitute new collateral. U.C.C. § 9204(a) cmt. 2. (AM. LAW INST. \& UNIF. LAW COMM'N 2000).

174 UNCITRAL Legislative Guide on Secured Transactions, supra note 4, Recommendations 13, 17 (explaining that the law should provide that a security right may encumber future assets).

175 UNCITRAL Draft Model Law on Secured Transactions, supra note 5, art. 6(2) ("A security agreement may provide for the creation of a security right in a future asset, but the security right in that asset is created only at the time when the grantor acquires rights in it or the power to encumber it.").

176 See supra Part 2.2.2.

177 See supra Part 2.2.1.

178 See Mooney, Rocks \& Schwartz, supra note 51, 49 Bus. L. at 1902 (“By facilitating the use of security entitlements and securities accounts as collateral for lenders other than the debtor's securities intermediary, Revised Article 8 and the proposed revisions to Article 9 promise to enhance financing prospects and lower costs of financing in both the retail and wholesale markets.").

179 See supra Part 3.

180 GSC arts. 12(1), (4)(a) (providing that the SA approach applies to a transfer of any interest in intermediated securities under Article 12 and is not limited to 
The foregoing discussion suggests that adoption of the CASA approach in Japan could provide useful flexibility. For example, it would address the situations reflected in Examples 4 and 5. It also would accommodate short-term transactions, such as overnight repo transactions, without the need for book entries and the involvement of a transferee's intermediary. The CA-SA approach would, moreover, facilitate the development of otherwise unavailable transactional patterns and financing arrangements. As explained in Part 4, the approach has proved to be feasible and useful in the United States and has received significant international blessing from its incorporation into the GSC. Of course, adoption of the CA-SA approach in Japan would not ensure that it would be widely utilized. But we see no reason to continue to exclude a potentially useful financing tool from the Japanese legal toolbox. Also as discussed in Part 6, in our view it is quite plausible that the approach would find favor with participants in the Japanese markets.

\subsection{Implications for Priority Rules and Priority Contests}

Because the BETA book-entry pledge or jōto tanpo book-entry transfer contemplates a single credit to a single pledgee or transferee (either to its pledge section or to its proprietary section for jōto tanpo), it leaves no room for priority contests. 181 Were Japan to adopt the CA approach or the CA-SA approach, however, it would be possible to create effective but conflicting interests in the same intermediated securities. It follows that such adoption would make it necessary also to adopt appropriate priority rules. ${ }^{182}$ Hap-

security interests). Curiously, perhaps, the SA approach is applicable under UCC Article 9 but does not expressly apply to transfers of interests other than security interests. See supra Part 2.2.1. However, we are not aware of any reason why the adoption of the SA approach should be ineffective in the case of such outright transfers if so agreed by the parties to a transfer.

181 See Mooney \& Kanda, Core Issues, supra note 9, at 114 (providing an overview of the operation and functions of the BETA).

182 The possibility of a junior security interest is sometimes thought to be beneficial. In the circumstance where the value of the collateral exceeds the amount secured by a senior security interest, the availability of a junior security interest frees up additional collateral to secure credit extended to the debtor, to the end that both obligations could be satisfied from the same collateral. Under current Japanese law, a similar result could be achieved by pledging certain securities to one pledgee and different securities to another pledgee. In any event and 
pily, because both the UCC and the GSC offer similar, although not identical, sets of priority rules, Japan need not reinvent the wheel in order to adapt these rules (or a variation) for the CA (or CA-SA) approach under the BETA.

The occurrence of second-priority security interests may not be commercially significant in the context of movables generally or securities in particular. However, by accommodating the creation of junior security interests that are generally effective against third parties, the CA approach would offer additional flexibility and could make feasible some transactions that otherwise would not take place under current law. ${ }^{183}$

Under the baseline priority rule that we advance here, conflicting security interests that become effective against third parties pursuant to control agreements generally would rank in priority according to the time that the security interests become effective against third parties. 184 However, as to after acquired securities covered by a control agreement, the time that the control agreement is entered into should be the relevant time for priority purposes. ${ }^{185}$ While this baseline rule would accommodate reaching the appropriate results in practice, in some cases it would not operate strictly as a "priority" rule. This is because the CA-SA ap-

regardless of the utiltiy of providing for junior security interests, the CA-SA approach would necessitate the adoption of such priority rules.

183 On the possible benefits of junior security interests, see supra note 178.

184 See U.C.C. § 9-328(2) (AM. LAW INST. \& UNIF. LAW COMM'N 2000) (stating that conflicting security interests perfected by control generally rank in priority in time of obtaining control); GSC art. 19(3) (providing that interests generally rank according to time of becoming effective against third parties). Note that the UCC priority rule necessarily embraces complications that would be unnecessary under our proposal for the BETA. That is in part because a security interest perfected by control has priority over a security interest perfected by another method. U.C.C. $\S$ 9-328(1) (AM. LAW INST. \& UNIF. LAW COMM'N 2000). A security interest in a security entitlement (including a securities account) may be perfected by filing a financing statement in the appropriate public registry. U.C.C. § 9-312(a) (AM. LAW INST. \& UNIF. LAW COMM'N 2000) (discussing perfection of security interest in investment property by filing.) Also, an additional complication arises because it is possible to obtain control of certificated and uncertificated securities in addition to control of security entitlements. See, e.g., U.C.C. § 8-106(a) (AM. LAW INST. \& UNIF. LAW COMM'N 2000) (control of certificated security in beaer form), (b) (control of certificated security in registered form), (c) (control of uncertificated security).

185 If the GSC version of the definition of control agreement were adopted, however, the time that the intermediary receives notice of the control agreement would apply if the intermediary were not a party to the agreement. See GSC arts. 1(k) (defining "control agreement," quoted in part supra note 82); 19(3) (detailing the priority ranking of "interests that become effective against third parties under Article 12"). 
proach would apply not only to security interests, including jōto tanpo transfers, but also to outright title transfers of full ownership interests in book-entry securities. If a first-in-time control agreement were to make effective such an outright transfer, a later transfer (of any kind) to which a later-in-time control agreement were applicable would not be a "second priority" or "junior" interest because the second-in-time transferee would have received no interest whatsoever - the account holder would have had no remaining interest to transfer. ${ }^{186}$

Our proposal contemplates only two methods for a pledge or other transfer to be made effective against third parties (i.e., methods of perfection) - by a book-entry, either a pledge or another book-entry transfer, as under the current BETA, or through a control agreement. ${ }^{187}$ In our view the method of perfection-bookentry or control agreement-should not bear on the question of general effectiveness as against third parties. Instead, the perfection regime should encourage parties to select the perfection method that is most efficient for their circumstances and the nature and terms of their transaction.

Notwithstanding this general preference for neutrality as between methods of third-party effectiveness, perfection by book entry necessarily would provide an advantage over perfection by control agreement. The temporal (first in time) priority rules for perfection by control agreement mentioned above should apply only with respect to competing interests in the same securities account. For example, assume that an account holder's securities ac-

186 The discussion in the text assumes that the described result would derive from either non-BETA law or would need to be provided in the BETA itself. The discussion also assumes that the priority rule would treat all security interests, including and jōto tanpo transfers, as equivalents. But one could imagine that a jo to tanpo transfer might be treated as an outright transfer of full ownership for these purposes. The result described in the text is explained in the Official Commentary to the GSC, inasmuch as Article 12 of the GSC also applies to any type of transfer of an interest in intermediated securities. OFFICIAL COMMENTARY, supra note 113, at 124-25 (Example 19-12).

187 As explained above, however, the proposal also is entirely compatible with a regime for perfection by compliance with a public notice regime such as filing or registration with a public official or registry. See supra note 145 and accompanying text. However, that alternative would require an additional priority rule. Consistent with the approach taken in the UCC, a transfer perfected by compliance with such a public notice regime should be subordinate to a transfer perfected by a control agreement. See U.C.C. § 9-328(1) (AM. LAW INST. \& UNIF. LAW COMM'N 2000) (providing that a secuity interest perfected by control has priority over security interest perfected by another method). 
count is debited by its intermediary, but wrongly so because the account was subject to a control agreement in favor of a creditor holding a security interest. Assume further that (directly or indirectly) corresponding with that debit another pledgee's pledge section (or a transferee's proprietary section in the case of a jōto tanpo transfer) is credited. In that case the interest of the second-in-time pledgee or transferee should have priority over (or should cut off) the interest of the first-in-time transferee pledgee if the second pledgee or transferee satisfies an appropriate test of good faith or innocence. ${ }^{188}$ It would be necessary to add such a test to the BETA to accommodate situations such as the example just posited. ${ }^{189}$

Both the UCC and the GSC incorporate another exception to the temporal priority rule for perfection by control agreement. Each provides a special priority rule when the interest in intermediated securities in acquired by the account holder's own intermediary. ${ }^{190}$ Under the UCC, "a security interest held by a securities intermediary in a security entitlement or a securities account maintained with the securities intermediary has priority over a conflicting security interest held by another secured party."191 The GSC takes a contrary approach: If an intermediary has an interest that is effective against third parties and thereafter effects a designating entry or enters into a control agreement for the benefit of another person, the other person's interest has priority over the interest of

188 See U.C.C. § 8-502 (AM. LAW INST. \& UNIF. LAW COMM'N 1994) (providing that a person acquiring security entitilement for value and without notice of an adverse claim is not liable for action based on the adverse claim); GSC art. 18(1) (providing that unless acquirer of interest in securities or intermediated securities knows or has reason to know of another person's interest and that acquisition violates rights of the other person, (i) acquirer's interest is not subject to other person's interest, (ii) acquirer is not liable to other person, and (iii) interest of acquirer is not invalid or reversible).

189 It is possible that under the BETA as currently in effect, such conflicts could occur, for example, between an account holder whose account was wrongfully debited and an onward transferee of book-entry securities. In an appropriate case, an onward transferee could cut off the interest of such an account holder. Under the BETA, an innocent account holder will acquire complete ownership of securities, i.e., free of competing property claims, if it receives a credit in good faith and without gross negligence. See BETA arts. 77 (corporate debt securities), 102 (JGBs), 144 (corporate equity securities); Mooney \& Kanda, Core Issues, supra note 9 , at 103 (providing an explanation for the operation and functions of the BETA). However, that issue and other issues that such a conflict would raise are beyond the scope of this paper.

190 This is the transactional pattern involved in Example 2, supra Part 4., and Example 3, supra Part 5.3

191 U.C.C. § 9-328(3) (AM. LAW INST. \& UNIF. LAW COMM'N 2000). 
the intermediary. ${ }^{192}$

In practice these two facially contrary priority rules often would lead to similar results. A prospective creditor, whether an intermediary or a third party, that would otherwise be subordinated under the applicable priority rule can choose to condition its extension of credit upon the conflicting (or potentially conflicting) party's agreement to subordinate its interest. In the absence of such a subordination agreement the new credit would not be extended and no priority contest would ensue. For example, under the UCC approach, a prospective third party lender could insist that the intermediary subordinate its existing (or any future) interest to the new lender's interest. Similarly, under the GSC approach, an intermediary could insist on a prospective third party lender's subordination as a condition to making a designating entry or entering into a control agreement. On the plausible assumption that market participants that would be affected by these priority rules are financial institutions and other professionals, we doubt that they would give rise to any surprises once the rules were put in place.

We are agnostic as to which approach-UCC or GSC - to intermediary priority should be taken by Japan in adopting the CASA approach. Consequently, we would favor the approach that would face the weakest political opposition and the strongest political support, to the end that the reforms proposed here would be more likely to be adopted. 193

192 This priority rule applies "unless that other person and the intermediary expressly agree otherwise". GSC art. 19(4).

193 Anecdotally, and based on Mooney's involvement with drafting the relevant provisions of both the UCC and the GSC (see notes 12,51, supra), the approach suggested in the text also influenced the substance of those instruments. The UCC drafters were quite sensitive to the potential opposition of the securities industry to the concept of perfection by control. Obviously, subordinating the interests of intermediaries to later-in-time third party interests would not have appealed to those advancing the interests of securities intermediaries. In similar fashion, the pervasive attitudes in the room during the GSC negotiations tended to favor the protection of innocent third parties over intermediaries, especially when a third party would have no way to discover an intermediary's pre-existing interest. 


\subsection{Right of Retention under Japanese Civil Code (Minpō) and Commercial Code (Shōhō)}

Certain provisions of the Minpō and the Shō hō suggest a possible alternative to the proposed CA-SA approach for addressing the Pledgee's situation in Example 4. These provisions provide a creditor with a "right of retention" under certain circumstances. ${ }^{194}$ One possible problem with the application of either right of retention would be the apparent conflict between such a right and an intermediary's obligation to comply with its account holder's instructions under the BETA.195 Under Minpō Article 295(1) if a possessor of a "thing" (movable) owned by another person has a claim that has fallen due with respect to the thing, the possessor may retain possession of the thing until the claim is satisfied.196 In the United States vernacular, the possessor has the equivalent of a statutory lien on the thing possessed securing the possessor's claim. However, Article 295(1) in its current form would be inadequate for addressing Pledgee's situation in Example 4. First, Pledgee's claim for repayment of the loan is not a "claim . . . with respect to" the securities that were not pledged to Pledgee. The relevant "claim" (Pledgor's obligation to repay the loan from Pledgee to Pledgor) appears to be wholly unrelated to those securities.

Shō hō Article 521 provides a somewhat similar but broader right of retention that applies to a claim of a merchant against another merchant arising out of a commercial transaction, but only if

194 MinPō Art. 295 (“Content of Rights of Retention”); SHō Hō [Commercial Code] art. 521 ("Right of Retention of Merchants").

195 See BETA arts. 66 (corporate debt securities), 88 (JGBs), 128 (corporate equity securities) (account holder's right to be reflected by record of a credit); 70 (corporate debt securities), 95 (JGBs), 132 (corporate equity securities) (upon account holder's instruction the intermediary "must" enter debits and credits account). An intermediary might seek a benefit analogous to a right of retention by obtaining its account holder's agreement that after the account holder's default in its obligations to the intermediary the intermediary would be relieved of its obligation to comply with the account holder's instructions. Arguably such an agreement would be unenforceable as being against public policy or as controvening the intermediary's duties under the BETA. Similarly, adopting the CA approach would require a clear and specific amendment of the BETA given the existing statutory obligation of an intermediary to follow its account holder's instructions.

196 MinPō [Civil Code] Art. 295(1) ("If a possessor of a Thing belonging to another person has a claim that has arisen with respect to that Thing, he/she may retain that thing until that claim is satisfied; provided, however, that this shall not apply if such claim has not yet fallen due."). 
the claim is due. ${ }^{197}$ Under Article 521, the claimant may retain an "object or negotiable instrument of value ... until the claim is satisfied."198 Article 521 applies only if the obligor on the claim owns the object or instrument and the claimant has possession pursuant a commercial transaction. ${ }^{199}$ As with Minpō Article 295, Article 521 might not provide adequate protection for Pledgee in the context of Example 4. It is controversial whether book-entry securities can be recognized as an "object or negotiable instrument of value" within the meaning of Shō hō Article 521. There are cases regarding paper promissory notes in which the courts have approved a right of retention claimed by banks while the banks possessed the notes for discount or collection and the owner had entered insolvency proceedings. ${ }^{200}$ Citing these cases, some have strongly argued that a party, such as an account holder's intermediary, should not lose the right simply because securities are dematerialized. At the same time, others question whether book-entry securities can be "possessed," and if they can be possessed, then by whom. ${ }^{201}$ Because only account holders have ownership of book-entry securities under the BETA, arguably the account holders, not the intermediaries, would "possess" them.202 In that case an intermediary

197 Article 521 provides:

When any claim between merchants arising from an act that constitutes a commercial transaction for both parties is due, the obligee may retain any object or negotiable instruments of value owned by the obligor of which the obligee has taken possession by way of the commercial transaction with the obligor, until the claim is satisfied; provided, however, that this shall not apply where the parties manifest their intention otherwise.

SHō Hō Art. 521 (emphasis added). A more faithful English translation of the Japanese would substitute the word "any" for the italicised "the" in the quoted text. The commercial transaction in connection with which the ogligee has taken possession need not be the same commercial transaction from which the claim arose.

198 Id.

199 Id.

200 Saikō Saibansho [Sup. Ct.] Jul. 14, 1998, Hei 7 (o) no.264, 52 SAIKō SAIBANSHO MinjI HANREISHŪ [MiNSHū] 1261 (Japan) (possession for discount, torided "nnder HASAN Hō ); Saikō Saibansho [Sup. Ct.] Dec. 15, 2011, Hei 22 (ju 受) no. 16, 65 SAIKō SAIBANSHO Minji HANREISHū [Minshū] 3511 (Japan) (possession for collection, decided under Civil Rehabilitation Act).

201 Shigeyuki Maeda, Shasaikabusikitōfurikaehō niokeru Yūkashōken no Pēpāresuka to Shōjiryūchiken no Seihi, in 22 KINYŪ Hō MU KENKYū KAI Hō KOKUSHO, YŪ KASHō KEN NO PĒPĀ RESUKAT̄̄ NI TOMONAU TANPOKENNADO KINYŪ TORIHIKI NIKAKARU Hō TEKIMONDAI 1, 4-11 (2013). However, for purposes of the right of retention we see no policy justification for differing treatment for paper promissory notes (or certificated securities) and book-entry securities.

202 Hiroki Morita, Yūkashōken no Pēpāresuka no Riron, 25 Kinyū kenkyū, 
would not possess the securities for purposes of Shō hō Article 521. Furthermore, the loan in Example 4 may or may not be a commercial transaction (depending on its purpose) ${ }^{203}$ and Pledgor and Pledgee may or may not be merchants within the meaning of Article 521.204

Assuming that these rights of retention (in their current forms) would not apply in the context of Example 4, if the right of retention were thought to be the appropriate approach the provisions (or one of them) could be modified so as to apply explicitly in the context of book-entry securities under the BETA. ${ }^{205}$ However, in our view the CA-SA approach for transactions governed by the BETA is the better approach. ${ }^{206}$ First, a right of retention that

Nov. 2006, at 1, 39-40.

203 For example, the loan could have been made to Pledgor, a natural person, for personal, family or household purposes.

204 For example, credit unions (Shinyōkinko, Shinyōkyōdōkumiai) are nonprofit corporations that provide financial support for Japanese citizens, and therefore the Supreme Court decided that a credit union is not a "merchant" within the meaning of the Shō hō, even though their businesses have expanded and are now quite similar to that of banks in general. Saikō Saibansho [Sup. Ct.] Oct. 5, 1973, Sho 46 (o) no.781, 726 HANReI JiHō 92 (Japan); Saikō Saibansho [Sup. Ct.] Oct. 18, 1988, Sho 59 (o) no. 557, 42, SAIKō SAIBANSho Minji Hanreishū [Minshū] 575 (Japan).

205 See Denshitekikiroku ni motozuku kenri wo meguru hō ritsumondai kenkyū kai, supra note 138, at 57-58 (suggesting such an approach with respect to Shō hō Article 521).

206 The Financial Law Board in Japan has suggested:

Where it may not be so clear that interpreted intermediated securities could be as "object of negotiable instrument of value" under SHō Hō Article 521, and there is concern to apply the right of retention widely, especially in a bankruptcy procedure, we should be amending SHō Hō to include intermediated securities under Article 521 clearly. Or another option would be introducing "control agreement" method into the BETA following with the GSC and the UCC.

Financial Law Board, Furikaekabushikitō to Shōjiryūchiken no Seihi nitsuite, KINYū Hō MUIIJ̄̄ , No.2052, 38, at 44 - 45, note 20 (2016). The Board has expressed further concerns as well:

Where a Japanese intermediary holds domestic intermediated securities (issued in Japan) and foreign intermediated securities (issued outside Japan) for its customers, the different governing laws might be applied for those securities according to international private law for intermediated securities in Japan. Since the legal effect of retention of right may vary in jurisdictions and might cause unexpectedly different results, it could be appropriate to provide widely accepted method of "control agreement", agreed by parties, for secured transactions in the BETA.

Id.

The Financial Law Board is a committee of Japanese attorneys and scholars who 
would confer on a securities intermediary in all cases a statutory lien on all securities credited to an account holder's account to secure all obligations of the account holder to the intermediary would be too broad. While the parties might opt out of the right of retention by agreement, ${ }^{207}$ we suspect that in the vast majority of situations this would not occur because account holders typically would not initiate negotiations to opt out of the right of retention. The CA-SA approach, however, would respect party autonomy by leaving the securities to be covered by a transfer (either the securities account or only discrete securities) to the agreement of the parties and without shifting the burden to the account holder to negotiate for an opt out, or narrowing, of the right of retention. Stated otherwise, we doubt that a default rule providing such a broad right of retention would reflect the bargain that parties would typically strike were the matter to be negotiated.

Second, an expanded and targeted right of retention as contemplated above would not address the situation of the third-party lender in the context of Example 5. Moreover, such a broad right of retention would reduce the transaction costs for the securities intermediary as a lender when compared to a third party transferee under a CA-SA regime. This could result in an uneven playing field and a less competitive credit market for account holders as prospective borrowers.

One might infer from the carefully restricted scope of the rights of retention under current law that a broad right with respect to any property in the possession of a claimant in respect of any obligation of the owner of the property has not found favor with policy makers in the legislative process. Were the rights of retention to be expanded to cover the account holder-securities intermediary situ-

specialize in financial law, and the Bank of Japan serves as its Secretariat. "The Board aims to propose recommendations on specific legal issues, in respect of uncertainties that may cause practical difficulties in introducing new financial products and transactions." Financial Law Board, About Us (available at: http://www.flb.gr.jp/epage/eabout.htm). For more information on the Board, see, http://www.flb.gr.jp/epage/ehome.htm.

207 Note that Shō hō Art. 521, quoted note 193, provides that it "shall not apply where the parties manifest their intention otherwise." This clearly contemplates the possibility of a contractual waiver of a right of retention arising under the Shō hō. On the other hand, the Minpō does not provide an explicit opt out provision. However, a creditor (such as a holder of a right of retention) may agree to a moratorium on payment by its debtor, thus delaying the accrual of a right of retention. Consequently, it is understood that a party can effectively waive the right of retention under the Minpō by means of such a moratorium. See Dō GAUCHI, supra note 136, at 15-16. 
ation, it seems likely that adjustments would be required to accommodate the specific context of book-entry securities in the BETA system. Given this, while we do not take a strong position, it might be preferable to adopt the CA-SA approach within the BETA rather than making adjustments to provisions of more general application in the Minpō and the Shō hō. In sum, while an expansion of the right of retention to embrace explicitly book-entry securities might be appropriate, that move would not provide an adequate substitute for the more flexible CA-SA approach and the party autonomy that the CA-SA approach embraces.

Finally, while we prefer the CA-SA approach as a modification of the BETA pledge rules, we note that the SA approach draws some policy support from the rights of retention just discussed. In each case the preferential rights are conferred on a claimant with respect to all of the relevant property in the claimant's possession (in the case of the rights of retention) or control (in the case of the SA approach).

\section{TRAnsactional ConteXt in JAPAN: ARE The Proposed REVISIONS A GOOD FIT, A WASTEFUL DIVERSION, OR A PRUDENT RISK?}

This Part first considers the question of whether and to what extent commercial law rules should, and do, reflect and support existing commercial practices or, instead, channel and influence commercial practices. Most probably would agree that the issue posed is not an "either-or" matter and that properly understood commercial law rules both reflect and channel commercial practices. At the outset we note our priors in the context of the proposed CA-SA approach for the BETA: Because security interests in and other transfers (such as in repos) of book-entry securities represent important commercial transactions in Japan, adjustments in the rules governing such transfers that provide more flexibility and lower transactions costs are presumptively beneficial and, absent unusual circumstances, should be adopted. On the other hand, if there are strong indications that, for some reason, such adjustments would not be accepted and used in fact, then such "reforms" might not be worth the effort. (No one enjoys hosting a party to which no one else shows up.)

Consider first an example drawn from UCC Article 9. Until 
the promulgation and subsequent enactment of Revised Article 9,208 with very limited exceptions ${ }^{209}$ perfection of a security interest in an "instrument" 210 could be accomplished "only by the secured party's taking possession." 211 The official comments to Section 9304 of the 1978 Official Text of the UCC explained:

With respect to instruments subsection (1) provides that ... taking possession is the only available method [of perfection] ... The rule is based on the thought that where the collateral consists of instruments, it is universal practice for the secured party to take possession of them in pledge; any surrender of possession to the debtor is for a short time; therefore it would be unwise to provide the alternative of perfection for a long period by filing which, since it in no way corresponds with commercial practice, would serve no useful purpose. ${ }^{212}$

The comment suggests that the rule permitting perfection only by possession emanates from "universal practice." But, of course that would be universal practice inasmuch as taking possession was the only means of achieving long-term perfection! It seems clear enough that in the security interest context practice followed the statute, not the other way around. Revised Article 9 now permits perfection of a security interest in instruments by filing a financing statement. ${ }^{213}$ Once again, practice follows the statute. ${ }^{214}$

208 See note 51 and accompanying text.

209 U.C.C., 1978 Official Text (AM. LAW INST. \& UNIF. LAW COMM'N 1978), Id. at § 9-304(4), (5) (temporary perfection for 21 days in limited circumstances); Id. at 9-306(2), (3) (continuation of security interest and continuation of perfection in proceeds).

210 Id. at § 9-105(1)(i) (defining "[i]nstument" as "a negotiable instrument ... or any other writing which evidences a right to the payment of money and is not itself a security agreement or lease and is of a type which is in ordinary course of business transferred by delivery with any necessary indorsement or assignment").

211 Id. at $\S 9-304(1)$ ); see also Id. at $\S 9-305$ (perfection by possession).

212 Id. at $\S 9-304 \mathrm{cmt} .1$.

213 Id. § 9-312(a).

214 As the official comment to UCC section 9-312 explains:

Under subsection (a), a security interest in instruments may be perfected by filing. This rule represents an important change from former Article 9, under which the secured party's taking possession of an instrument was the only method of achieving long-term perfection. The rule is likely to be particularly useful in 
There is some evidence as well from Japan that reforms in secured transactions law will influence commercial practices and that market participants will adjust their behavior to take account of such changes in the legal framework. Consider, for example, the PRAMC. ${ }^{215}$ The PRAMC was introduced to address the issue of a lack of public notice in the case of outright transfers of movables for security ( $j \bar{o}$ to tanpo) transactions. ${ }^{216}$ (As explained in Part V.A., however, any objection to the CA approach based on the absence of public notice would not be persuasive.) One study found that banking practices adjusted to the PRAMC in that a substantial number of filings for transfers of title had been made with the Tokyo Registration Office. ${ }^{217}$ Moreover, following the effectiveness of the PRAMC firms specialized in asset-based financing commenced doing business in Japan. ${ }^{218}$ In addition, bank regulators have recognized "movables as appropriate security as long as the secured assets are adequately managed and reasonably evaluated." 219 While these adjustments may not be striking, they suggest that it is quite plausible that financing practices would adjust to the adoption of the CA-SA approach under revisions to the BETA.

We do not suggest that these examples necessarily demonstrate that the CA-SA approach would be widely accepted and employed in practice were Japan to adopt the proposed revisions to the BETA. Ultimately, policymakers should weigh the costs and benefits of adopting the CA-SA approach for the BETA and the likelihood that it would find favor in the market. However, we

transactions involving a large number of notes that a debtor uses as collateral but continues to collect from the makers.

$I d$. at § 9-312 cmt. 2. Note that even when perfection by filing is available for instruments, a secured party may wish to take possession of an instrument in order to prevent a good faith purchaser from cutting off or subordinating the secured party's interest. See Id. at § 3-306 (holder in due course of negotiable instrument take free of conflicting claims); 9-330(d) (good faith purchaser for value which takes possession of instrument without knowledge of violation of rights of another secured party having security interest perfected other than by possession has priority over other secured party's security interest).

215 PRAMC, supra note 27.

216 Kozuka \& Fujisawa, Old Ideas, supra note 117 at 299.

217 Id. at 301-02, 308-09.

218 Id. at 309.

219 Id. ("This policy change is in accordance with the Basel Accord II," citing Basel Committee on Banking Supervision, International Convergence of Capital Measurement and Capital Standards: A Revised Framework, Comprehensive Version, Bank for Int'l Settlements paras. 289, 509-24 (June 2006), http:// www.bis.org/publ/bcbs128.pdf [https://perma.cc/F2A7-K9XZ]. 
submit that any evaluation of the benefits of the CA-SA approach in the BETA environment should not be limited to a consideration of only existing transactional contexts in which the approach might be applied or to the specific transactions that presently might be envisioned. In this connection, decades of experience in the United States financial markets should be considered. The CA approach has provided a useful and flexible tool for the creation of interests in securities that are effective against third parties without the necessity of book entries. The CA approach has provided this flexibility by building on predecessor transactional patterns, such as triparty repo transactions, in contexts as varied as secured commercial loans and secured loans to individual investors. The flexibility of the CA approach has permitted parties to allow for a wide range of options with respect to nature and extent of access and power over securities by an account holder and transferees. The SA approach also has accommodated flexibility and efficiency through the "floating lien" attributes of security interests in any securities that from time to time may be credited to a securities account. And under the CA-SA approach, such interests may be made effective by a single control agreement. In our view it is quite plausible that the CA-SA approach would be embraced by and found to be quite useful in the Japanese financial markets.

\section{SUMMARY AND CONCLUSIONS}

Following the Introduction we explained the operation of a control agreement method of perfection and the concept of security interests in securities accounts. The discussion drew on the development of these concepts in the drafting history of UCC Articles 8 and 9 and the GSC. After outlining our proposal for incorporating these features into Japanese law, we examined pledges of securities under the BETA and the revisions that would be necessary to incorporate the CA-SA approach. We next offered our policy analyses of the CA-SA approach. We explained how the CA method of perfection would be conceptually consistent with traditional Japanese property law, including deliveries of movables under the Minpō without an actual change of possession, assignments of nominative claims under the Minpō, and transfers by book entries under the BETA.

We conclude that adopting the CA-SA approach under the 
BETA would offer transactional flexibility. In particular, the CA approach could address risks of undersecurity as reflected by Examples 4 and 5 and could accommodate short term transactions without the need for book entries and involvement of a transferee's intermediary. Moreover, the CA approach would facilitate the "floating lien" feature contemplated the SA approach for security interests and other interests in securities accounts as securities move in and out of an account. We suggest that it is plausible that the CA-SA approach would facilitate the emergence of new, more flexible transactional patterns in the Japanese markets. Finally, our discussion of the CA-SA approach also provides a platform for a further, and future, consideration of a more comprehensive modernization of Japanese secured transactions law. 